\title{
Mouse germ line mutations due to retrotransposon insertions
}

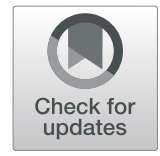

\author{
Liane Gagnier ${ }^{1}$, Victoria P. Belancio ${ }^{2}$ and Dixie L. Mager ${ }^{1 *}$ (D)
}

\begin{abstract}
Transposable element (TE) insertions are responsible for a significant fraction of spontaneous germ line mutations reported in inbred mouse strains. This major contribution of TEs to the mutational landscape in mouse contrasts with the situation in human, where their relative contribution as germ line insertional mutagens is much lower. In this focussed review, we provide comprehensive lists of TE-induced mouse mutations, discuss the different TE types involved in these insertional mutations and elaborate on particularly interesting cases. We also discuss differences and similarities between the mutational role of TEs in mice and humans.
\end{abstract}

Keywords: Endogenous retroviruses, Long terminal repeats, Long interspersed elements, Short interspersed elements, Germ line mutation, Inbred mice, Insertional mutagenesis, Transcriptional interference

\section{Background}

The mouse and human genomes harbor similar types of TEs that have been discussed in many reviews, to which we refer the reader for more in depth and general information [1-9]. In general, both human and mouse contain ancient families of DNA transposons, none currently active, which comprise $1-3 \%$ of these genomes as well as many families or groups of retrotransposons, which have caused all the TE insertional mutations in these species. As in humans [4], the mouse genome contains active retrotransposon families of long and short interspersed repeats (LINEs and SINEs) that can cause germ line mutations via new insertions but, in contrast to humans, the mouse also contains several groups of retrotranspositionally active endogenous retroviral elements (ERVs) that are responsible for most reported insertional mutations.

\section{ERVs/LTR retrotransposons}

ERVs are the result of retroviral infections or retrotranspositions in the germline. The general structure of an ERV is analogous to that of an integrated provirus, with flanking long terminal repeats (LTRs) containing the transcriptional regulatory signals, specifically enhancer,

\footnotetext{
* Correspondence: dmager@bccrc.ca

${ }^{1}$ Terry Fox Laboratory, BC Cancer and Department of Medical Genetics,

University of British Columbia, V5Z1L3, Vancouver, BC, Canada

Full list of author information is available at the end of the article
}

promoter and polyadenylation motifs and often a splice donor site $[10,11]$. Sequences of full-length ERVs can encode gag, pol and sometimes env, although groups of LTR retrotransposons with little or no retroviral homology also exist [6-9]. While not the subject of this review, ERV LTRs can often act as cellular enhancers or promoters, creating chimeric transcripts with genes, and have been implicated in other regulatory functions [1113]. The mouse genome contains many different groups of ERVs and related LTR retrotransposons that together comprise $\sim 10 \%$ of the sequenced genome [1] and which have been characterized to varying extents $[6,9,14,15]$. ERVs in mouse and other vertebrates are generally categorized into three classes. Class I ERVs are most related to the exogenous gamma-retroviral genus, Class II to betaand alpha-retroviruses and Class III to spuma-retroviruses $[6,9]$. The very large non-autonomous MaLR (mammalian apparent LTR retrotransposon) group is also considered Class III but has only very small traces of retroviral homology. Different mammals have distinct collections of ERVs and the mouse is unusual in having a much higher fraction of Class II elements compared to humans or other mammals $[1,6]$. For all but very young groups, the majority of ERV loci exist only as solitary LTRs, the product of recombination between the $5^{\prime}$ and $3^{\prime}$ LTRs of integrated proviral forms [16, 17]. Moreover, for ERVs that have not undergone this recombination event, most have

(c) The Author(s). 2019 Open Access This article is distributed under the terms of the Creative Commons Attribution 4.0 International License (http://creativecommons.org/licenses/by/4.0/), which permits unrestricted use, distribution, and reproduction in any medium, provided you give appropriate credit to the original author(s) and the source, provide a link to the Creative Commons license, and indicate if changes were made. The Creative Commons Public Domain Dedication waiver (http://creativecommons.org/publicdomain/zero/1.0/) applies to the data made available in this article, unless otherwise stated. 
lost coding competence due to mutational degradation over time.

Unlike human ERVs that are likely no longer capable of autonomous retrotransposition [18, 19], some mouse ERVs are retrotranspositionally active and are significant ongoing genomic mutagens in inbred strains, causing 10 $12 \%$ of all published germ line mutations via new integration events $[1,20]$. The large Intracisternal A-particle (IAP) ERV group is responsible for close to half the reported mutations due to new ERV insertions, with the Early Transposon (ETn)/MusD ERV group also contributing substantially [20](Fig. 1a). These groups and other mutation-causing ERVs will be discussed in more detail in the subsequent relevant sections. The majority of mutagenic ERV insertions occur in introns and disrupt normal transcript processing (e.g. splicing and polyadenylation) to varying degrees, a mechanism well recognized since the 1990s [21-25] and discussed further below.

\section{Long interspersed repeats (LINEs)}

LINE-1s (L1s) are autonomous non-LTR elements that have accumulated to as many as 500,000 copies in both mouse and human genomes using a copy-and-paste mechanism of amplification [1-3, 26]. Full length L1s are $6-7 \mathrm{~kb}$ and contain two open reading frames (ORFs) encoding ORF1p and ORF2p, with the latter having endonuclease and reverse transcriptase activity [27-30]. The number of potentially active L1s (i.e. full-length elements containing intact ORFs) varies significantly between human and mouse. Bioinformatics analyses of the reference genomes have documented 2811 mouse and 146 human L1s that are fully structurally intact [31]. Functional studies have estimated numbers of active L1s to be $\sim 3000$ for mouse [32] and 80-100 for human [33]. In contrast to the human genome that has had a single subfamily of LINEs active at any given evolutionary time, the mouse genome contains three concurrently active L1 subfamilies (T(F), A, and $G(F))$ [32, 34] that are insertionally polymorphic among strains $[17,35]$. One of the distinguishing features of these subfamilies is the differing $5^{\prime}$ monomer tandem repeats which, when combined with a downstream non-monomeric sequence, form their 5' UTRs [36]. The 5' UTR also contains the L1 pol II promoter, which occurs downstream of the transcriptional start site [37, 38], an arrangement common to non-LTR retrotransposons [39], allowing the promoter to be retained in the L1 mRNA.

Mouse and human L1s contain promoters, splice and polyadenylation signals in both sense and antisense directions that are utilized during L1 and host gene transcription, also sometimes leading to the formation of chimeric mRNAs [40-44]. As with ERVs [20, 45], such cis-acting sequences are a likely reason for the negative impact of some intronic L1 insertions on gene expression [43]. De novo L1 inserts can vary in size from just a few bases to those containing a full-length L1 sequence [26], with the vast majority of such inserts being 5 '-truncated to varying extents. Although the exact mechanisms underlying this truncation phenomenon remain unclear, there is a positive correlation between the frequency of retrotransposition and insert length [46], and cellular DNA repair interference with L1 integration may play a role $[47,48]$.

Sporadically, new germ line L1 insertions cause mutations when they land in or near a gene in human [4] or mouse (discussed below), and somatic insertions can also occur, although few of the latter have been shown to exert a significant biological effect [49-51]. Mutagenic L1 inserts can potentially disrupt normal gene function or expression by interfering with it directly or by introducing deletions or complex genomic rearrangements that are sometimes associated with the integration process $[3,52]$. In addition to introducing de novo insertions containing L1 sequences, L1 can mobilize flanking

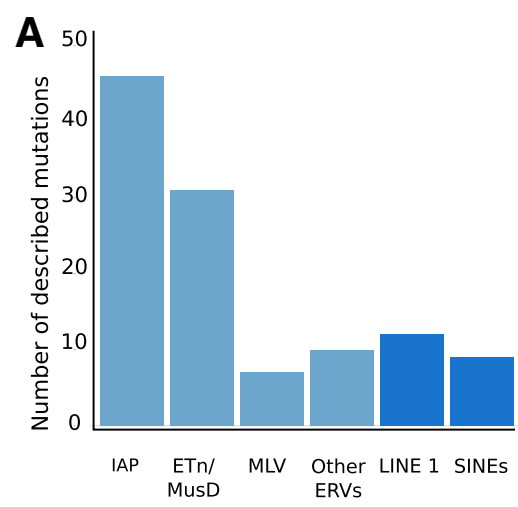

B
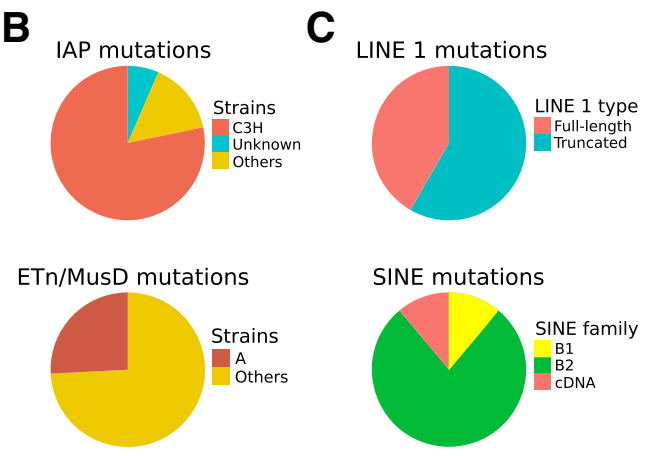

Fig. 1 Distribution of mouse mutations caused by TE insertions. a Numbers of published mutations caused by different TE types. $\mathbf{b}$ Strain bias for IAP and ETn/MusD insertional mutations. c Upper panel - proportion of LINE1 insertional mutations that are full length or near full length. Lower panel shows high proportion of B2 SINEs among insertional mutations 
genomic sequences as well. This occurs as a result of their incorporation into the nascent L1 mRNA generated by either inaccurate/upstream transcriptional initiation ( $5^{\prime}$ transduction) or inefficient transcriptional termination at the L1 $3^{\prime}$ polyadenylation site resulting in readthrough and 3 ' transduction $[3,53,54]$. Recent analysis of endogenous L1 expression in human cell lines determined that only about a third of expressed L1 loci generate such readthrough transcripts [55] but a similar analysis has not been performed for mouse. The uniqueness of these transduced sequences are often useful in identifying the source L1 element responsible for a newly retrotransposed copy [56].

\section{Short interspersed repeats (SINEs)}

SINE elements are non-autonomous retrotransposons, as they do not encode proteins involved in their amplification. As with human Alu SINE sequences [57], mouse SINEs have been shown to be retrotransposed by mouse L1 [58]. Only one of the two L1 proteins (ORF2p) is sufficient to drive Alu SINE mobilization in tissue culture [57], although ORF1p enhances the process [59]. Both mouse and human L1s can efficiently mobilize their non-orthologous SINEs, suggesting that such a symbiotic relationship has evolved multiple times [58-62]. There are several SINE classes in the mouse genome that together comprise $~ 8 \%$ of the genome [1]. Among these are B1, B2, B4/RSINE, ID, and MIR. New mutagenic insertions have been documented for B1 and B2 (see below), indicating that at least some copies are still potentially active. B1 (like human Alu) is derived from 7SL RNA, and B2 is derived from tRNA [3]. B1 and B2 SINEs are both present at very high genomic copy numbers: $\sim 560,000$ for B1 and $\sim 350,000$ for B2 [1]. Like mouse L1s and ERVs, these mouse SINEs are insertionally polymorphic in inbred strains $[17,63,64]$.

\section{Cataloging TE-induced mouse mutations}

We assembled lists of mutations caused by TEs by perusing the literature and by querying the Mouse Genome Informatics (MGI) database of mutant alleles [65]. In October 2018 we obtained lists from MGI of all spontaneous mutant alleles that listed "viral", "transposon" or "insertion" as the cause and extracted all relevant cases through manual curation. To avoid ascertainment bias, we excluded cases where investigators were specifically screening for effects of insertionally polymorphic TEs $[35,66,67]$. While such cases can show effects on gene expression, observable phenotypes due to these insertionally polymorphic TE insertions were not reported in the aforementioned studies. In addition, we excluded cases where the insertion event likely occurred in cultured ES cells used to produce transgenic mice. Nearly all arose spontaneously but two cases of mutations occurring during a chemical mutagenesis experiment, but likely not caused by the chemical mutagen, were also included. This search resulted in a total of 115 TE insertion mutations. Ninety-four of these were caused by insertions of ERVs/LTR retroelements and 21 were L1 or L1-mediated (Fig. 1). In the case of the ERV mutations, the tables shown here are updates of previously published lists [1, 20,68].

\section{IAP insertion mutations}

The group of ERVs responsible for the most reported mutations are the IAP elements. IAP sequences are Class II elements and are highly abundant in the mouse $[6,69]$. Different estimates for IAP copy number exist in the literature but a recent analysis of all sequences annotated "IAP" by Repeatmasker [70] found 3000 solitary LTRs and $\sim 2800$ full-length or partial full-length elements in the reference C57BL/6 genome [71]. Of the latter, 1000 have $5^{\prime}$ and 3' LTRs that are 100\% identical, indicative of a very young age, and most of these belong to the IAPLTR1 or 1a subtypes [71]. As expected for such a young ERV group, IAP elements are highly insertionally polymorphic among inbred mouse strains [17, $66,67,72]$. Although $\sim 200$ IAP sequences (IAPE elements) contain an env gene [73], most do not. Loss of env and other specific genetic modifications facilitated adoption of an intracellular retrotranspositional life cycle by IAPs [74] resulting in their accumulation to high copy numbers as genomic "super spreaders" [75]. Besides the lack of env, there are a few common partly deleted proviral forms [69] with the most notable being the $1 \Delta 1$ subtype, which has a $1.9 \mathrm{~kb}$ deletion removing part of $g a g$ and pol, resulting in an ORF encoding a novel gag-pol fusion protein. Although retrotransposition of $1 \Delta 1$ proviruses is non-autonomous, requiring gag and pol proteins in trans from other IAPs [76], this subtype is responsible for the great majority of new IAP insertion mutations [20]. Interestingly, it has been shown that the gag-pol fusion protein functions in cis to facilitate retrotransposition [77]. Together with a generally higher level of $1 \Delta 1$ transcripts compared to full length IAP mRNAs (see below), this cis effect could explain why most new insertions are of the $1 \Delta 1$ subtype.

Although transgenic experiments have shown expression of an IAP LTR only in the male germ line [78], endogenous IAP transcription is also detectable in embryogenesis as early as the two cell stage and appears highest in the morula and blastocyst stages [79]. Moreover, at least some IAP elements can be transcribed in normal somatic tissues, particularly in the thymus, where a specific subtype of IAP LTR shows transcriptional activity [80, 81]. Notably, the levels of $1 \Delta 15.4 \mathrm{~kb}$ IAP transcripts are comparable or often more abundant than full-length IAP transcripts in different tissues or cell 
types [69, 80, 82], although the former are present in lower copy numbers $[69,71,83]$. The molecular mechanisms underlying the generally higher transcript levels of $1 \Delta 1$ elements are unknown but one possibility is that these elements are more likely to escape the general epigenetic transcriptional repression of IAPs by DNA methylation and repressive histone modifications [84-87].

Table 1 lists mouse germ line mutations caused by insertions of IAPs. Somatic insertions of IAP elements can also occur and cause oncogene or cytokine gene activation in mouse plasmocytomas, myelomas and lymphomas [8890], likely due to the fact that some IAP LTRs are transcriptionally active in lymphoid tissues [80, 81]. Most of the germ line insertions occur in gene introns and disrupt transcript processing, notably splicing and polyadenylation (Table 1) [20]. However, several IAP-induced mutations involve ectopic gene transcription promoted by an upstream or intronic inserted LTR that is regulated by DNA methylation [20,91]. In these cases, the IAP is oriented in the opposite transcriptional direction with respect to the gene and it is an antisense promoter within the LTR that is responsible for the ectopic gene transcription. For a number of such cases, including the most well studied $\mathrm{A}^{\mathrm{vy}}$ allele of agouti [92], variable establishment of epigenetic repressive marks on the IAP LTR result in variable expressivity of the mutant (IAP) allele in genetically identical mice and have been termed metastable epialleles [91, 93]. Interestingly, a recent genome-wide screen for other IAP metastable epialleles in C57BL/6 mice identified $\sim 100$ such loci, with an enrichment of flanking CTCF binding sites as the primary distinguishing feature [94].

\section{IAP activity in $\mathrm{C} 3 \mathrm{H}$ mice}

Because high numbers of IAP mutations in $\mathrm{C} 3 \mathrm{H}$ mice and high IAP insertional polymorphisms among $\mathrm{C} 3 \mathrm{H}$ substrains have been noted before [20,83], we investigated the strain of origin for all TE-induced mutations. For IAPs, the strain of origin could not be ascertained for three of the 46 cases but, of the remaining 43 , a remarkable $84 \%$ (36 cases) occurred in a C3H strain or hybrid involving $\mathrm{C} 3 \mathrm{H}$ (Table 1, Fig. 1b). This marked skew is not seen for mutations caused by any other retroelements, indicating that ascertainment bias cannot explain the high frequency of IAP-caused mutations in $\mathrm{C} 3 \mathrm{H}$ mice. While the date of the mutation is difficult to determine in some cases, IAP retrotranspositions in $\mathrm{C} 3 \mathrm{H}$ mice have spanned several decades, with the earliest reported cases in the 1950s and the latest in 2014 (Table 1 ). This indicates that the unusual IAP activity has been a characteristic of $\mathrm{C} 3 \mathrm{H}$ strains for at least 60 years. Indeed, Frankel et al. have shown that at least $261 \Delta 1$ IAP insertions present in $\mathrm{C} 3 \mathrm{H} / \mathrm{HeJ}$ are absent from the highly related $\mathrm{C} 3 \mathrm{HeB} / \mathrm{FeJ}$ substrain [83], again indicative of ongoing activity of IAPs, particularly the $1 \Delta 1$ subtype, in this strain.

Although reasons for the numerous IAP insertional mutations in $\mathrm{C} 3 \mathrm{H}$ strains are unknown, it is noteworthy that normal spleen, bone marrow and thymus from $\mathrm{C} 3 \mathrm{H} / \mathrm{He}$ mice have much higher levels of IAP transcripts compared to C57BL/6 and STS/A mice [95], suggesting that transcriptional deregulation may be involved. As well, IAPs are transcriptionally upregulated in radiation-induced acute myeloid leukemia in $\mathrm{C} 3 \mathrm{H} / \mathrm{He}$ mice, resulting in new insertions in the leukemic cells, most of which are of the $1 \Delta 1$ subtype $[95,96]$. These observations, coupled with the fact that most new mutations in $\mathrm{C} 3 \mathrm{H}$ mice involve the $1 \Delta 1$ subtype suggests that this IAP subtype is accumulating in the $\mathrm{C} 3 \mathrm{H}$ genome at a faster rate than full length elements.

Two recent reports illustrate the prudence of considering IAP induced mutations whenever working with $\mathrm{C} 3 \mathrm{H}$ mice (Fig. 2). In the first case, Frankel et al. found that an IAP insertion in the $P c n x 2$ gene in $\mathrm{C} 3 \mathrm{H} / \mathrm{HeJ}$ mice $\left(\mathrm{Pcn} \times 2^{\mathrm{C} 3 \mathrm{H} / \mathrm{HeJ}}\right)$ reduces expression of this gene, which in turn mitigates the effect of an IAP insertion in Gria4 $\left(G r i a 4^{s p k w 1}\right.$ ) which causes seizures [83]. Hence one IAP insertion modifies the effect of another (Fig. 2a). In another intriguing example, Barau et al. conducted a screen in $\mathrm{C} 3 \mathrm{HeB} / \mathrm{FeJ}$ mice using $N$-ethyl- $N$-nitrosourea (ENU) mutagenesis to identify genes involved in retrotransposon silencing in the germ line [97]. They identified several lines with the same mutation, indicating it was not induced by ENU but rather was spontaneous. This mutation was an IAP element inserted in an intron of a gene, annotated as a non-functional pseudogene, that formed as a tandem duplication of Dnmt3B. Barau et al. showed that this gene, now termed Dnmt3C, is indeed a functional DNA methyltransferase responsible for methylating promoters of young retroelements, including L1 elements and IAPs, in the male germ line [97]. Therefore, an IAP insertion facilitated the discovery of a gene involved in its own silencing (Fig. 2b).

\section{$\mathrm{C} 3 \mathrm{H}$ mouse history}

The $\mathrm{C} 3 \mathrm{H}$ strain was derived by Leonard Strong from a 1920 cross of a Bagg albino female (ancestors to the BALB/c strain) and a male from Little's strain of "dilute browns" (ancestors to the DBA strain) [98]. One of the original female progeny of this mating developed spontaneous mammary tumors and this trait was selected for or against by subsequent inbreeding to develop the $\mathrm{C} 3 \mathrm{H}$ strain (highly susceptible to mammary tumors) and the CBA strain (highly resistant). Mouse mammary tumor virus (MMTV), the transmissible agent responsible for the early onset mammary tumors in $\mathrm{C} 3 \mathrm{H}[99,100]$, was later purged from most $\mathrm{C} 3 \mathrm{H}$ related strains by pup fostering or re-derivation. In particular, the most widely 
Table 1 IAP insertions

\begin{tabular}{|c|c|c|c|c|c|c|}
\hline${ }^{\mathrm{a}}$ Mutation & MGI ID ${ }^{b}$ & Strain of origin & $\begin{array}{l}\text { Year } \\
\text { mutation } \\
\text { arose }\end{array}$ & $\begin{array}{l}\text { Location \& } \\
\text { Orientation }\end{array}$ & Mutational mechanism(s) or effects & References \\
\hline$\overline{{ }^{a} A^{h v y}}$ & 1855945 & $\mathrm{C} 3 \mathrm{H} / \mathrm{HeJ}$ & $\sim 1994$ & Exon $1 C_{1}{ }^{c}$ & $\begin{array}{l}\text { IAP forms } 5^{\prime} \text {-end of transcript }{ }^{d} \text {, Regulation by } \\
\text { methylation }\end{array}$ & [181] \\
\hline${ }^{a} A^{\text {iapy }}$ & 1856403 & C57BL/6J xC3H male & 1992 & Intron, - & $\begin{array}{l}\text { IAP forms } 5 \text { '-end of transcript }{ }^{d} \text {, Regulation by } \\
\text { methylation }\end{array}$ & [182] \\
\hline$A^{i y}$ & 1855933 & $\mathrm{C} 3 \mathrm{H} / \mathrm{HeJ}$ & 1964 & Intron 1,- & $\begin{array}{l}\text { IAP forms } 5^{\prime} \text {-end of transcript }{ }^{d} \text {, transcript } \\
\text { contains internal IAP sequence }\end{array}$ & [183] \\
\hline${ }^{a} A^{v y}$ & 1855930 & $\mathrm{C} 3 \mathrm{H} / \mathrm{HeJ}$ & 1960 & Exon $1 \mathrm{~A},-$ & $\begin{array}{l}\text { IAP forms } 5 \text { '-end of transcript }{ }^{d} \text {, Regulation by } \\
\text { methylation }\end{array}$ & {$[92,183]$} \\
\hline Adamts $13^{5}$ & 3579136 & unknown, present in several strains & ? & Intron $23,+$ & $\begin{array}{l}\text { IAP causes premature polyadenylation and } \\
\text { protein truncation. Reduced enzyme activity } \\
\text { but no obvious phenotype }\end{array}$ & {$[184,185]$} \\
\hline$A p 3 d 1^{m h-2 J}$ & 1856084 & $\mathrm{C} 3 \mathrm{H} / \mathrm{HeJ}$ & $\begin{array}{l}\text { Before } \\
1988\end{array}$ & Intron $21,+$ & $\begin{array}{l}\text { Transcript contains internal IAP sequence, } \\
\text { Truncated protein }\end{array}$ & [186] \\
\hline Atcay ${ }^{i-h e s}$ & 1856898 & $\mathrm{C} 3 \mathrm{H} / \mathrm{HeJ}-\mathrm{Tyr}^{\mathrm{c}-\mathrm{a}}$ & 1987 & Intron 1,+ & Transcript contains internal IAP sequence & [187] \\
\hline Atp2b2 $2^{j o g}$ & 3664103 & $\begin{array}{l}\text { DSO, derived from } \mathrm{C} 3 \mathrm{H} / \mathrm{He}-\mathrm{Pw} \\
\text { hybrid }\end{array}$ & 2000 & Intron,+ & $\begin{array}{l}\text { Reduced mRNA levels, likely by terminating } \\
\text { at poly(A) in IAP, also cryptic splicing } \\
\text { suggested }\end{array}$ & [188] \\
\hline$A t r n^{m g}$ & 1856081 & $\mathrm{C} 3 \mathrm{H}$ - Swiss stock cross & 1950 & Intron 26, - & $\begin{array}{l}\text { Transcript contains internal IAP sequence, } \\
\text { Truncated protein, Likely termination in IAP }\end{array}$ & [189] \\
\hline $\operatorname{Atrn}^{m g-L}$ & 2156486 & $\mathrm{C} 3 \mathrm{H} / \mathrm{HeJ}$ & 1981 & Intron $27,+$ & $\begin{array}{l}\text { Transcript contains internal IAP sequence, } \\
\text { Reduced protein levels, Likely termination in } \\
\text { IAP }\end{array}$ & [189] \\
\hline${ }^{a}$ Axin $1^{F u}$ & 1856035 & Bussey stock & $\begin{array}{l}\text { Before } \\
1931\end{array}$ & Intron 6, - & $\begin{array}{l}\text { IAP forms } 5^{\prime} \text {-end of transcript }{ }^{\text {d }} \text {, Regulation by } \\
\text { methylation, and transcript contains internal } \\
\text { IAP sequence, Truncated protein }\end{array}$ & {$[190,191]$} \\
\hline${ }^{a} A x i n 1^{F u-k b}$ & 1856037 & unknown & $\begin{array}{l}\text { mid } \\
1970 s ?\end{array}$ & Exon 7,- & $\begin{array}{l}\text { IAP forms } 5^{\prime} \text {-end of transcript }{ }^{d} \text {, transcript } \\
\text { contains internal IAP sequence, Internally } \\
\text { deleted protein }\end{array}$ & [190] \\
\hline $\mathrm{Clcci}^{\mathrm{mis}}$ & 5618134 & $\mathrm{C} 3 \mathrm{H} / \mathrm{HeSnJ}$ & $\begin{array}{l}\text { After } \\
1947\end{array}$ & Intron 2,+ & $\begin{array}{l}\text { Transcripts contains internal IAP sequence, } \\
\text { Reduced normal mRNA levels }\end{array}$ & [192] \\
\hline Cryge $^{\text {No3 }}$ & 3713105 & $\mathrm{C} 3 \mathrm{H} / \mathrm{HeH} \times 102 / \mathrm{E} 1 \mathrm{~F} 1$ & $\begin{array}{l}\text { Late } \\
1990 \text { s }\end{array}$ & Exon $3,+$ & $\begin{array}{l}\text { Reduced mRNA levels, Transcript contains } \\
\text { internal IAP sequence, Truncated protein }\end{array}$ & [193] \\
\hline $\mathrm{Dab} 1^{\mathrm{scm}}$ & 1856801 & $\begin{array}{l}\text { Dc/Le (Dc arose in an obese stock } \\
\text { outcrossed to BALB/c } \times \mathrm{C} 3 \mathrm{H} / \mathrm{He} \\
\text { hybrid. One cross to } \mathrm{C} 3 \mathrm{H} / \mathrm{HeJ} \text {, then } \\
\text { inbred.) }\end{array}$ & 1991 & Intron, - & $\begin{array}{l}\text { Transcript contains internal IAP sequence, } \\
\text { Truncated protein }\end{array}$ & {$[194,195]$} \\
\hline$D n m t 3 C^{1 A P}$ & N & $\begin{array}{l}\text { C3HeB/FeJ } \\
\text { From chemical induction exp. }\end{array}$ & $\sim 2014$ & Last intron, - & $\begin{array}{l}\text { IAP provides alternate splice acceptor site, } \\
\text { resulting in exclusion of Dnmt3C last exon, } \\
\text { chimeric Dnmt3C-IAP mRNA }\end{array}$ & {$[97]$} \\
\hline Eyal $1^{\text {bor }}$ & 1857803 & C3HeB/FeJ & 1984 & Intron $7,+$ & $\begin{array}{l}\text { Transcript contains internal IAP sequence, } \\
\text { Reduced mRNA levels }\end{array}$ & {$[25]$} \\
\hline Gataj $^{j a l}$ & 3027100 & $\mathrm{C} 3 \mathrm{H} / \mathrm{HeJ}$ & $1990 \mathrm{~s}$ & Intron 3,- & Unknown & [196] \\
\hline Gpr179nob5 & 5431477 & $\mathrm{C} 3 \mathrm{H}$ & $\begin{array}{l}\text { After } \\
1951\end{array}$ & Intron $1,+$ & Drastically reduces gene expression & {$[197,198]$} \\
\hline Gria4 $4^{\mathrm{spkw1}}$ & $\begin{array}{l}3580141 \\
\text { (QTL) }\end{array}$ & $\mathrm{C} 3 \mathrm{H} / \mathrm{HeJ}$ & $\begin{array}{l}1950- \\
2002\end{array}$ & Intron $15,+$ & $\begin{array}{l}\text { Full-length protein expression is significantly } \\
\text { reduced }\end{array}$ & [199] \\
\hline Gusb $^{m p s-2\lrcorner}$ & 2152564 & $\mathrm{C} 3 \mathrm{H} / \mathrm{HeOuJ}$ & $\begin{array}{l}\text { mid } \\
1990 s ?\end{array}$ & Intron $8,+$ & $\begin{array}{l}\text { Reduced mRNA size and level, No enzyme } \\
\text { activity detected }\end{array}$ & {$[200]$} \\
\hline$H p s 3^{\text {coa-6J }}$ & 1861609 & $\mathrm{C} 3 \mathrm{H} / \mathrm{HeJ}$ & $1999 ?$ & Exon $10,-$ & Transcript contains internal IAP sequence & [201] \\
\hline$H p s 1^{e p}$ & 1856712 & $\mathrm{C} 3 \mathrm{HeB} / \mathrm{FeJ}$ & 1957 & $\begin{array}{l}\text { 3'-coding } \\
\text { exon, - }\end{array}$ & $\begin{array}{l}\text { Transcript contains internal IAP sequence, } \\
\text { Protein contains IAP-encoded amino acids }\end{array}$ & {$[202]$} \\
\hline$H p s 6^{r u-6 J}$ & 1856410 & $\mathrm{C} 3 \mathrm{H} / \mathrm{HeJ}$ & 1995 & Unknown, + & $\begin{array}{l}\text { Kidney: loss of expression, Brain: transcript } \\
\text { contains IAP sequence }\end{array}$ & {$[203]$} \\
\hline Kcnq $]^{v t g-2\lrcorner}$ & 2389447 & $\mathrm{C} 3 \mathrm{H} / \mathrm{HeJCrl}-1 / 2^{\mathrm{tm} 1 \mathrm{Hor}}$ & $\sim 2000$ & Exon 2,- & $\begin{array}{l}\text { IAP fusion transcript likely promoted by } \\
\text { antisense LTR. IAP provides } 5^{\prime} \text { end of } 31 \mathrm{bp} \\
\text { fused in frame to the gene. }\end{array}$ & [204] \\
\hline
\end{tabular}


Table 1 IAP insertions (Continued)

\begin{tabular}{|c|c|c|c|c|c|c|}
\hline${ }^{a}$ Mutation & MGI ID ${ }^{b}$ & Strain of origin & $\begin{array}{l}\text { Year } \\
\text { mutation } \\
\text { arose }\end{array}$ & $\begin{array}{l}\text { Location \& } \\
\text { Orientation }\end{array}$ & Mutational mechanism(s) or effects & References \\
\hline $\operatorname{LamB3}^{\mid A P}$ & 2179716 & $\begin{array}{l}\mathrm{C} 3 \mathrm{H} \text { (C3Hf/R1 male bred separately } \\
\text { from JAX for decades) }\end{array}$ & $\sim 1990$ & $\begin{array}{l}\text { Intron/exon } \\
\text { junction }\left(5^{\prime}\right) \\
-\end{array}$ & $\begin{array}{l}\text { Transcript contains internal IAP sequence, No } \\
\text { mRNA or protein expression }\end{array}$ & [205] \\
\hline Mclr ${ }^{\mathrm{mpc} 59 \mathrm{H}}$ & 5791971 & C3H.Pde6b & 2010 & Exon,? & Disruption of single exon gene & {$[206]$} \\
\hline$M g r n 1^{m d}$ & 1856070 & $\mathrm{C} 3 \mathrm{H} / \mathrm{HeJ}$ & $\sim 1960$ & Intron $11,+$ & $\begin{array}{l}\text { Reduced mRNA levels, aberrantly sized } \\
\text { transcripts }\end{array}$ & {$[207,208]$} \\
\hline$M g r n l^{m d-2\lrcorner}$ & 1856072 & $\mathrm{C} 3 \mathrm{H} / \mathrm{HeJ}$ & $\begin{array}{l}1978- \\
1993\end{array}$ & Exon $12,+$ & $\begin{array}{l}\text { Reduced mRNA levels, aberrantly sized } \\
\text { transcripts }\end{array}$ & {$[207,208]$} \\
\hline$M g r n 7^{m d-5 J}$ & 1856519 & $\mathrm{C} 3 \mathrm{H} / \mathrm{HeJ}$ & $\begin{array}{l}1978- \\
1993\end{array}$ & Intron $2,+$ & Not characterized & {$[207,208]$} \\
\hline Oprmi $1^{\mid A P}$ & N & CXBK recomb. Inbred of B6 \& Balb & $\begin{array}{l}\text { Before } \\
1984\end{array}$ & Exon $4, ?$ & 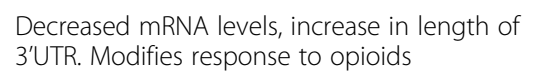 & [209] \\
\hline Pcnx2 $2^{\text {C3H/HeJ }}$ & 6161760 & $\mathrm{C} 3 \mathrm{H} / \mathrm{HeJ}$ & $\begin{array}{l}\text { After } \\
1950\end{array}$ & Intron $19,+$ & $\begin{array}{l}\text { Modifier of Gria4 mutation, reduces Pcnx2 } \\
\text { expression }\end{array}$ & [83] \\
\hline Pitpna ${ }^{v b}$ & 1856642 & $\mathrm{DBA} / 2 \mathrm{~J}$ & $\begin{array}{l}\text { Early } \\
1960 \text { s }\end{array}$ & Intron $4,+$ & $\begin{array}{l}\text { Transcript contains internal IAP sequence, } \\
\text { Reduced mRNA \& protein }\end{array}$ & [210] \\
\hline Pla2g6 $6^{m 11}$ & 4412026 & $\mathrm{C} 3 \mathrm{H} / \mathrm{HeJ}$ & $\begin{array}{l}\operatorname{mid} \\
2000 \mathrm{~s}\end{array}$ & Intron 1,? & Reduces normal gene transcripts by 90\% & [211] \\
\hline Plcd $3^{\text {mNab }}$ & N & $\mathrm{C} 3 \mathrm{H}$ mix & $\sim 2005$ & Intron 2,- & $\begin{array}{l}\text { Causes truncated protein, LTR may act as } \\
\text { antisense promoter? }\end{array}$ & [212] \\
\hline Pofut ${ }^{\text {cax }}$ & 3719000 & $\mathrm{C} 3 \mathrm{H} / \mathrm{HeJ}$ & $\begin{array}{l}\text { mid } \\
2000 \text { s }\end{array}$ & Intron 4, & Reduced mRNA and protein levels & [213] \\
\hline $\operatorname{Rel}^{r-A l b 2}$ & 1857345 & $\begin{array}{l}\mathrm{C} 3 \mathrm{H} / \mathrm{HeJ} \\
\text { From chemical ind. Exp. }\end{array}$ & $\sim 1990$ & Exon 36, - & Exon skipping, Reduced mRNA levels & [214] \\
\hline$S / C 35 d 3^{\mid A P}$ & 3802578 & $\mathrm{C} 3 \mathrm{H} / \mathrm{HeSn}-\mathrm{Rab} 27 \mathrm{a}^{\text {ash }} / \mathrm{JRos}$ & $\begin{array}{l}\text { 1980s- } \\
1990 s\end{array}$ & Exon 1,- & $\begin{array}{l}\text { IAP fusion transcript likely promoted by } \\
\text { antisense LTR. IAP provides } 5^{\prime} \text { end of } 18 \mathrm{bp} \\
\text { fused in frame to the gene. }\end{array}$ & [215] \\
\hline Spta1 ${ }^{\text {sph-Dem }}$ & 2388936 & $\begin{array}{l}\text { CcS3/Dem recomb. Con. strain } \\
\text { from BALB/CHeA and STS/A }\end{array}$ & 1991 & $\begin{array}{l}\text { Intron 10/ } \\
\text { exon } 11 \\
\text { junction, + }\end{array}$ & $\begin{array}{l}\text { Exon skipping, Reduced protein expression, } \\
\text { Reduced } a-/ \beta \text {-spectrin dimer and tetramer } \\
\text { stability }\end{array}$ & [216] \\
\hline Tal1 ${ }^{\text {Hpt }}$ & 1859843 & C57BL/6J x C3HeB/FeJLe-a/a)F1. & 1979 & Intron $4,+$ & $\begin{array}{l}\text { Promotes overexpression of exons } 4 \text { and } 5 \text {, } \\
\text { fusion transcripts found. }\end{array}$ & {$[217]$} \\
\hline Tnfrsfl3 $c^{B c m d 1}$ & $\begin{array}{l}2389403 \\
(\mathrm{QTL})\end{array}$ & AMySnJ & $\begin{array}{l}\text { Before } \\
1991\end{array}$ & Exon $3,+$ & Fusion transcripts, Loss of function mutation & [218] \\
\hline Tyr $^{\mathrm{CmIOR}}$ & 2153728 & $\mathrm{C} 3 \mathrm{Hf} / \mathrm{R} 1$ & 1988 & Upstream, - & $\begin{array}{l}\text { IAP does not form 5'-end of transcript, } \\
\text { Reduced mRNA expression }\end{array}$ & [219] \\
\hline Usp $14^{a x-J}$ & 1855959 & CBA or kreisler stock & $\begin{array}{l}\text { Early } \\
1950 \text { s }\end{array}$ & Intron $5,+$ & $\begin{array}{l}\text { Transcript contains internal IAP sequence, } \\
\text { Reduced mRNA levels, } \\
\text { Truncated protein }\end{array}$ & [220] \\
\hline Wnt9b clf1 & 1856821 & A & $1920 \mathrm{~s}$ & $\begin{array}{l}\text { Downstream, } \\
+\end{array}$ & Produces transcript antisense to Wnt9b. & {$[221,222]$} \\
\hline$Z f p 69^{\mid A P}$ & N & $\begin{array}{l}\text { Unknown, } \\
\text { present in C57BL/6, NZO, } \\
\text { other strains }\end{array}$ & $?$ & $\begin{array}{l}\text { Intron } 3 \text { of } \\
\text { Zfp69, }+\end{array}$ & $\begin{array}{l}\text { IAP causes premature polyadenylation and } \\
\text { alternate splicing. Loss of functional Zfp } 69 \text { in } \\
\text { strains carrying the IAP is protective against } \\
\text { diabetes. }\end{array}$ & [223] \\
\hline 9630033F20Rik & N & $\mathrm{C} 3 \mathrm{H} / \mathrm{HeDiSnJ}$ & $\sim 1985 ?$ & Exon $5,-$ & $\begin{array}{l}\text { Deletion of exon } 5 \text {, decreased gene } \\
\text { expression. Occurs in "lew" mice with point } \\
\text { mutation in Vamp1 thought to be cause. IAP } \\
\text { may contribute. }\end{array}$ & {$[224,225]$} \\
\hline
\end{tabular}

${ }^{a}$ Variable phenotype or expression (metastable epiallele)

${ }^{b}$ ID number in Mouse Genome Informatics (MGI) database, "N" indicates not present in MGI

$c_{-}=$antisense, $+=$sense,? = orientation unknown

${ }^{\mathrm{d}}$ Ectopic expression of IAP-driven transcript 


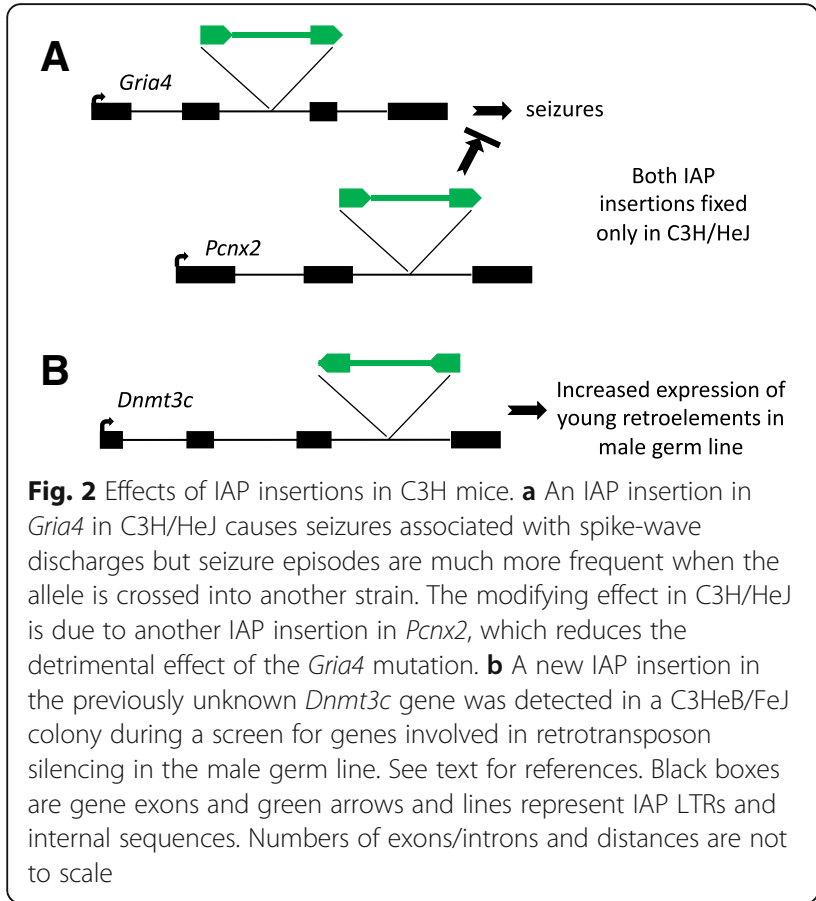

used $\mathrm{C} 3 \mathrm{H}$ substrain $\mathrm{C} 3 \mathrm{H} / \mathrm{HeJ}$ was re-derived to be MMTV-free at the Jackson Laboratory (JAX) in 1999 and all $\mathrm{C} 3 \mathrm{H}$ substrains carried at JAX have been free of MMTV since that time. Because IAP mutations have continued to occur in $\mathrm{C} 3 \mathrm{H} / \mathrm{HeJ}$ mice after removal of MMTV (Table 1), it is unlikely that activities of the two retroviral entities are directly related. Various substrains of $\mathrm{C} 3 \mathrm{H}$, including the commonly used $\mathrm{C} 3 \mathrm{H} / \mathrm{HeJ}$, were derived in the late 1940s and early 1950s [101].

Interestingly, there is some evidence that $\mathrm{C} 3 \mathrm{H} / \mathrm{HeJ}$ has a higher spontaneous mutation rate than most other strains. A multi-year study conducted at JAX from 1963 to 1969 examined over 7 million mice derived from 28 inbred strains for spontaneous observable and heritable mutations [102]. $\mathrm{C} 3 \mathrm{H} / \mathrm{HeJ}$ had marginally the highest overall rate of mutations but not remarkably so [102]. However, this study also documented mutational cases of "irregular inheritance" where the trait was heritable but showed very poor penetrance. Of the 35 examples of such cases, $16(46 \%)$ arose in $\mathrm{C} 3 \mathrm{H} / \mathrm{HeJ}$, even though this strain accounted for only $9.7 \%$ of the 7 million mice in the study [102]. It is tempting to speculate that at least some of these unusual cases may involve a new IAP insertion behaving as a metastable epiallele [91, 93].

\section{ETn/MusD insertion mutations}

After IAPs, the ETn/MusD group is responsible for the next highest number of germ line mutations, with 31 cases (Fig. 1, Table 2). ETn elements were first described as repetitive sequences expressed highly in early embryogenesis [103]. Subsequent expression analyses showed that ETns are transcribed in two windows of embryonic development. First during E3.5-7.5 in the inner cell mass and epiblast and second between E8.5-11.5 in various tissues including the neural tube, olfactory/nasal processes and limb buds [103-105]. Although ETns have LTRs, they have no coding capacity and, hence, their mode of retrotransposition was initially a mystery. Based on traces of retroviral homology in canonical ETns, we identified an ERV group, termed MusD, which is the likely progenitor of ETn $[106,107]$ and Ribet et al. demonstrated that coding competent MusD elements provide the machinery necessary for ETn elements to retrotranspose [108]. A subsequent phylogenetic analysis of the large betaretrovirus genus classified MusD as belonging to the Class II ERV- $\beta 7$ group [14]. One analysis of copy numbers of ETn and MusD in C57BL/6 found $\sim 240$ ETn elements, $\sim 100$ MusDs and $\sim 550$ solitary LTRs [107], and they are highly insertionally polymorphic [17, 66, 109]. As for IAP elements, loss of the env gene and other genetic modifications likely resulted in genomic amplification of MusD (and ETn) elements as intracellular retrotransposons [110]. In another similarity to IAPs, most germ line mutations caused by ETn/ MusD are due to insertions of the non-autonomous ETn (Table 2), in particular a specific subtype ETnII- $\beta$ [20]. Of the 31 cases, only three are documented to be MusD while the rest are ETn (Table 2). The reasons for this are not clear but ETn transcripts are much more abundant than MusD transcripts in embryos and ES cells [107, 111] and there is evidence that MusD is subject to greater levels of epigenetic suppression [111, 112].

ETn/MusD mutations do not show an extreme strain bias as observed for IAP insertions. However, eight mutations have occurred in "A" strain mice (Fig. 1b), such as $\mathrm{A} / \mathrm{J}$, and two in the seldom used strain SELH/Bc (Table 2) which has a high incidence of exencephaly [113, 114]. Interestingly, genomic copy number estimates in different mouse strains revealed that, while there are no detectable differences in MusD numbers, $\mathrm{A} / \mathrm{J}, \mathrm{SELH} / \mathrm{Bc}$ and $\mathrm{CD}-1$ mice have two to three times more ETnII- $\beta$ elements compared to C57BL/6 [107]. Transcript levels of MusD and ETnII- $\beta$ in day $7.5 \mathrm{em}-$ bryos are also higher in SELH/Bc and CD-1 compared to C57BL/6 [107].

Nearly all of the ETn mutagenic insertions occur in gene introns, in the same transcriptional direction as the gene, and disrupt normal transcript processing through utilization of canonical or cryptic signals within the ETn, notably a specific strong splice acceptor site in the LTR, coupled with either a downstream splice donor or polyadenylation signal $[20,45]$. This extreme orientation bias for mutagenic insertions is also observed for the intronic IAP insertions that do not involve IAP promoter activity (Table 1). Such an orientation skew for detrimental 
Table 2 ETn/MusD insertions

\begin{tabular}{|c|c|c|c|c|c|}
\hline Mutation & $M G I I D^{a}$ & Strain of origin & Location \& Orientation ${ }^{\#}$ & Mutational mechanisms or effects & References \\
\hline Adcyl $1^{b r l}$ & 1857405 & ICR & Intron $14,+^{\#}$ & $\begin{array}{l}\text { Transcripts contain ETn sequence, } \\
\text { Transcripts terminate within the ETn }\end{array}$ & {$[226,227]$} \\
\hline Bloc $155^{m u}$ & 1856106 & Stock-t & Intron $3,+$ & $\begin{array}{l}\text { Transcripts contain internal ETn } \\
\text { sequence }\end{array}$ & [228] \\
\hline Cacnalf fob2 & 3605845 & AXB6/PgnJ & Exon $2,+$ & $\begin{array}{l}\text { Premature termination and alternative } \\
\text { splicing within ETn }\end{array}$ & {$[229,230]$} \\
\hline $\operatorname{Cacng}^{\text {stg }}$ & 1856548 & $A / J$ & Intron $2,+$ & $\begin{array}{l}\text { Transcripts contain ETn sequence, } \\
\text { Probable termination within ETn }\end{array}$ & {$[231,232]$} \\
\hline Cacng $2^{\text {stg-wag }}$ & 1856386 & MRL/MpJ-Fas'pr/J & Intron $1,+$ & $\begin{array}{l}\text { Transcripts contain ETn sequence, } \\
\text { Probable termination within ETn }\end{array}$ & {$[231,232]$} \\
\hline Cacng $2^{\text {stg-3」 }}$ & 2155891 & $\mathrm{BALB} / \mathrm{CJ}$ & Intron $2,+$ & $\begin{array}{l}\text { Transcripts contain internal ETn } \\
\text { sequence }\end{array}$ & {$[231,232]$} \\
\hline $\mathrm{Clcn} 7^{\mathrm{adr}}$ & 1856316 & $\mathrm{~A} 2 \mathrm{G}$ & Intron $12,+$ & $\begin{array}{l}\text { Transcripts contain ETn sequence, } \\
\text { Termination within ETn }\end{array}$ & [233] \\
\hline Dsg $4^{\text {hage }}$ & 3766998 & Recom. inbred of MRL/Ipr $\times$ BXSB & Intron $8,+$ & $\begin{array}{l}\text { Aberrant splicing in ETn causes in frame } \\
\text { additional exon of } 63 \text { amino acids }\end{array}$ & [234] \\
\hline Dysf ${ }^{\text {prmd }}$ & 3055150 & $A / J$ & Intron $4,+$ & $\begin{array}{l}\text { ETn fixed in A/J strain. Aberrant splicing, } \\
\text { No detectable dysferlin protein }\end{array}$ & [235] \\
\hline EdaP Pl-slk & 1856017 & Stock Tyrp1 $1^{\mathrm{b}}$ Dock $7^{\mathrm{m}} \mathrm{Rb}(4.6) 2 \mathrm{Bnr}$ & unknown & $\begin{array}{l}\text { Transcripts contain ETn sequence, } \\
\text { Termination within ETn }\end{array}$ & [236] \\
\hline Em/1 heco & 5560734 & NOR-ICR & Intron 22, + & $\begin{array}{l}\text { Aberrant splicing and premature } \\
\text { termination, transcripts contain ETn } \\
\text { sequence }\end{array}$ & {$[237,238]$} \\
\hline$E \operatorname{Etn} 3^{P p d}$ & 3665247 & CD-1 & $1.6 \mathrm{~kb} 3^{\prime}$ of Dusp9 gene, - & $\begin{array}{l}\text { Upregulates Dusp9 in ES cells, causes } \\
\text { phenotype in Polypodia mutant }\end{array}$ & {$[120]$} \\
\hline Fas $^{l p r}$ & 1856334 & $\mathrm{MRL} / \mathrm{Mp}$ & Intron $2,+$ & $\begin{array}{l}\text { Transcripts contain ETn sequence, } \\
\text { Termination within ETn }\end{array}$ & {$[21,239,240]$} \\
\hline $\mathrm{Fb} \times w 4^{\mathrm{Dac}}$ & 1857833 & $\mathrm{SM} / \mathrm{Ckc}$ & $10 \mathrm{~kb} 5^{\prime}$ of exon $1,-$ & $\begin{array}{l}\text { No evident difference in size or } \\
\text { abundance of transcript, MusD* } \\
\text { insertion }\end{array}$ & {$[121-123]$} \\
\hline$F b x w 4^{D a c-2\lrcorner}$ & 1857834 & MRL/MpJ & Intron $5,+$ & $\begin{array}{l}\text { Small amounts of normal transcript, } \\
\text { MusD* insertion disrupts a conserved } \\
\text { motif in intron }\end{array}$ & {$[121-123]$} \\
\hline Fig $4^{p l t 1}$ & 3716838 & 'mixed' (129/Ola, C57BL/6J, C3H \& SJL) & Intron $18,+$ & $\begin{array}{l}\text { Abnormal splicing from exon } 18 \text { to SA } \\
\text { site of Etnll, very low abundance of } \\
\text { transcript }\end{array}$ & [241] \\
\hline Fign $^{f i}$ & 1856870 & Random bred & Intron $2,+$ & $\begin{array}{l}\text { Transcripts contain ETn sequence, } \\
\text { Probable termination within ETn }\end{array}$ & [242] \\
\hline Foxn $1^{n u-B C}$ & 1856110 & $\mathrm{SELH} / \mathrm{BC}$ & Intron, - & $\begin{array}{l}\text { Transcripts contain internal ETn } \\
\text { sequence }\end{array}$ & [113] \\
\hline Gli3 pdn & 1856282 & JCl:ICR & Intron $3,+$ & $\begin{array}{l}5 \text { alternatively spliced transcripts } \\
\text { contain ETn sequence, three terminate } \\
\text { within ETn, two terminate as wild-type }\end{array}$ & [243] \\
\hline$H k 1^{\text {dea }}$ & 2151848 & $A / J$ & Intron $4,+$ & $\begin{array}{l}\text { Probable aberrant splicing of ETn } \\
\text { sequences into mRNA, Decreased } \\
\text { hexokinase activity }\end{array}$ & [244] \\
\hline$H s f 4^{\mid d i s 1}$ & 3056560 & RIIIS/J & Intron $9,+$ & $\begin{array}{l}\text { ETn alters splicing resulting in a } \\
\text { chimeric truncated protein, and causes } \\
\text { at least } 100 \text { fold up-regulation of the } \\
\text { transcript }\end{array}$ & [245] \\
\hline$\left\lfloor e p^{o b-2\rfloor}\right.$ & 1858048 & $\mathrm{SM} / \mathrm{Ckc}-\mathrm{Fb} x w 4^{\mathrm{Dac}}$ & Intron $1,+$ & $\begin{array}{l}\text { Transcripts contain ETn sequence, } \\
\text { Probable termination within ETn, Loss } \\
\text { of leptin expression. }\end{array}$ & [23] \\
\hline Mip ${ }^{C a t-F r}$ & 1857104 & $A / J$ & Intron $3,+$ & $\begin{array}{l}\text { Transcripts contain ETn sequence, } \\
\text { Termination within ETn, LTR sequence } \\
\text { translated to protein domain }\end{array}$ & {$[246,247]$} \\
\hline
\end{tabular}


Table 2 ETn/MusD insertions (Continued)

\begin{tabular}{|c|c|c|c|c|c|}
\hline Mutation & MGI ID & Strain of origin & Location \& Orientation ${ }^{\#}$ & Mutational mechanisms or effects & References \\
\hline Rubie $e^{\text {SWR-J }}$ & 5568608 & SWR/J & Intron $1,+$ & $\begin{array}{l}\text { Aberrant splicing and premature } \\
\text { polyadenylation of the long non-coding } \\
\text { RNA transcript Rubie which is proposed } \\
\text { to regulate Bmp4 expression }\end{array}$ & [248] \\
\hline$S g k 3^{f z-i c a}$ & 3032837 & Swiss & Intron $6,+$ & $\begin{array}{l}\text { Aberrant splicing, transcript contains } \\
\text { ETn sequence }\end{array}$ & {$[249,250]$} \\
\hline $\operatorname{sil} 1^{\text {wz }}$ & 3055918 & Recomb. inbred CXB5/ByJ & Intron $7,+$ & $\begin{array}{l}\text { Aberrant splicing and premature } \\
\text { termination. Transcript contains ETn } \\
\text { sequence }\end{array}$ & [251] \\
\hline Slc6a5 $5^{m i s}$ & 5086232 & NOD.Cg-Emv30 Prkdc $^{\text {scid } / D v s ~}$ & Intron $5,+$ & $\begin{array}{l}\text { MusD* insertion, Inclusion of } 183 \text { bp of } \\
\text { MusD sequence in mRNA, complete } \\
\text { loss of protein }\end{array}$ & [252] \\
\hline $\operatorname{Ttc} 7^{f s n}$ & 1856879 & $A / J$ & Intron $14,+$ & $\begin{array}{l}\text { Transcripts contain internal ETn } \\
\text { sequence }\end{array}$ & [253] \\
\hline$T^{\text {Wis }}$ & 1857760 & $A / J$ & splice donor of exon 7,- & $\begin{array}{l}8 \text { alternatively spliced transcripts, } 4 \\
\text { contain ETn sequence, } 1 \text { terminates } \\
\text { within ETn, } 7 \text { terminate as wild-type, } 5 \\
\text { have exon skipping }\end{array}$ & {$[254,255]$} \\
\hline $\operatorname{Tyr}^{c-B C 3}$ & 1856303 & SELH/BC & Exon 1,- & $\begin{array}{l}\text { Transcripts probably contain ETn } \\
\text { sequence, Probable termination in ETn }\end{array}$ & [113] \\
\hline$Z h \times 2^{B A L B / C J}$ & 3623885 & $\mathrm{BALB} / \mathrm{CJ}$ & Intron $1,+$ & $\begin{array}{l}\text { Transcripts contain ETn sequence, } \\
\text { Termination within ETn }\end{array}$ & {$[256,257]$} \\
\hline
\end{tabular}

a ID number in Mouse Genome Informatics (MGI) database, "N" indicates not present in MGI

$\#_{-}=$antisense, $+=$sense, = orientation unknown

*MusD insertions are bolded. All others are ETns

insertions is indeed expected, given that fixed/older ERVs have an antisense bias in genes $[115,116]$, presumably reflecting the fact that such insertions are less likely to be potentially deleterious and selected against.

In an attempt to mechanistically understand these orientation biases, we modeled splicing events involving intronic ERVs (using computationally predicted splice and polyadenylation motifs) and surprisingly found similar predicted frequencies of alternate splicing caused by sense or antisense ERVs [45]. However, actual splicing patterns of human mRNAs with intronic ERVs suggests that suppression of splicing within antisense-oriented ERVs occurs, possibly via steric hindrance due to annealing of sense-oriented ERV mRNAs [45]. This scenario would be analogous to gene therapy approaches where oligonucleotides that anneal to and suppress the use of mutagenic splice sites are used to redirect splicing and restore gene function [117]. Although unproven, such a mechanism could contribute to the general antisense bias for neutral/fixed ERV insertions and the opposite bias for mutagenic insertions.

Unlike for IAPs, there are no documented cases of ETn promoters causing a phenotype by driving ectopic gene expression (Table 2). This is likely due at least in part to the fact that ETn/MusD LTRs are normally only transcriptionally active in embryogenesis, responding to embryonic transcription factors $[118,119]$, so their promoter/enhancer activity would be silent in somatic tissues where most observable but non-lethal phenotypes manifest themselves. There is, however, at least one case where enhancer effects of an ETn insertion are likely responsible for a mutant phenotype. In this example, an ETn insertion downstream of the Dusp 9 gene upregulates this gene and also causes malformations in Polypodia mice, although a direct link between Dusp 9 deregulation and malformations has not been shown [120].

There is an intriguing but complex story involving two of the three documented MusD insertions [121-123]. Both of these cause the dactylaplasia (Dac) embryonic limb malformation phenotype by insertions within $\left(F b x w 4^{D a c-2 J}\right)$ or upstream $\left(F b x w 4^{D a c}\right)$ of the $F b x w 4$ gene. Both are full length MusD elements that share 99.6\% identity and have occurred in different mouse strains. In the former case $\left(F b x w 4^{\text {Dac-2J }}\right)$, the intronic, sense oriented MusD severely reduces the amount of normal Fbxw4 transcripts, likely via typical transcript processing disruption or via physical disruption of a conserved, and hence potentially regulatory, $\sim 1.5 \mathrm{~kb}$ region within the intron [123], although neither mechanism has been formally demonstrated. In the other Dac mutation $\left(F b x w 4^{D a c}\right.$, also termed $\left.D a c^{1 J}\right)$ the MusD is inserted $10 \mathrm{~kb}$ upstream of the Fbxw4 gene in antisense orientation. However, no effects on the size or abundance of Fbxw 4 transcripts are evident in mice carrying this insertion, so the mechanism by which it causes dactylaplasia remains unclear [121-123].

Interestingly, the Dac phenotype is modified by an unlinked polymorphic locus mdac (modifier of 
Table 3 MLV Insertions

\begin{tabular}{|c|c|c|c|c|c|}
\hline Mutation & MGI ID ${ }^{a}$ & Strain of origin & ERV location, orientation ${ }^{\mathrm{b}}$ & Mutational mechanisms or effects & References \\
\hline$\overline{A b c b 1 a^{m d s}}$ & 3044239 & CF-1 & Solitary MLV LTR, Intron 22, - & $\begin{array}{l}\text { Transcripts contain viral sequence, Exon skipping, } \\
\text { Disruption of gene function. }\end{array}$ & $\overline{[258,259]}$ \\
\hline Aifm $1^{\mathrm{Ha}}$ & 1861097 & CF-1 & Intron $1,+$ & $\begin{array}{l}80 \% \text { decrease in transcript and protein levels, } \\
\text { Aberrant splicing }\end{array}$ & [260] \\
\hline$H r^{h r}$ & 1856057 & $\mathrm{HRS} / \mathrm{J}$ & Intron $6,+$ & $\begin{array}{l}\text { Transcripts contain viral sequence, Probable } \\
\text { termination within LTR }\end{array}$ & {$[24,137]$} \\
\hline $\operatorname{Lamc}^{\text {jeb }}$ & 3609880 & $129 \times 1 / S v J$ & $\begin{array}{l}\text { Solitary MLV LTR, } \\
\text { intron } 18,+\end{array}$ & $\begin{array}{l}\text { Aberrant splicing and premature termination, } \\
\text { low level of normal transcripts }\end{array}$ & [261] \\
\hline$L m f f^{c l d}$ & 1856820 & M. m. musculus & Intron $7, ?$ & $\begin{array}{l}\text { Transcripts contain ERV sequence, Termination } \\
\text { within ERV }\end{array}$ & [262] \\
\hline Myo5a $a^{d}$ & 1856004 & Fancy mice & Intron, + & $\begin{array}{l}\text { Shortened and abnormally spliced transcripts } \\
\text { that vary among tissues }\end{array}$ & [135] \\
\hline Pde6b $b^{\text {rd1 }}$ & 1856373 & unknown & Intron 1,- & $\begin{array}{l}\text { Associated with nonsense mutation in gene } \\
\text { but effect of ERV is unclear }\end{array}$ & [263] \\
\hline
\end{tabular}

${ }^{\mathrm{a}}$ ID number in Mouse Genome Informatics (MGI) database

$\mathrm{b}_{-}=$antisense, $+=$sense, ? = orientation unknown

dactylaplasia) [124]. In strains homozygous for the mdac allele (eg. BALB/c and A/J), the dactylaplasia phenotype is observed if the mice carry either dac mutation. However, in strains carrying the other allele Mdac (eg. CBA, $\mathrm{C} 3 \mathrm{H}$ or $\mathrm{C} 57 \mathrm{BL}$ ), the phenotypic effects of the dac mutations are not observed [122, 124]. Although the identity of $m d a c$ is still unknown, it could be a gene involved in epigenetic regulation of MusD. In mdac/mdac mice, the $5^{\prime}$ LTR of the Dac ${ }^{I J}$ MusD element is unmethylated and enriched in active histone marks whereas this LTR is heavily methylated and enriched in repressive histone marks in mice carrying the Mdac allele [122]. Moreover, ectopic MusD transcript expression is observed in embryos and limb buds of dactylaplasia mdac/mdac mice, but not in wildtype mdac/mdac mice, suggesting that the increased MusD expression is due to transcription of the $\operatorname{Dac}^{1 J}$ MusD element itself, rather than general upregulation of MusDs in the genome [122]. The mdac

Table 4 Other ERV Insertions

\begin{tabular}{|c|c|c|c|c|c|}
\hline Mutation & MGI ID & Strain of Origin & ERV, Location, Orientation ${ }^{\mathrm{b}}$ & Mutational mechanisms or effects & $\overline{\text { References }}$ \\
\hline Agtpbp $1^{p c d-2\lrcorner}$ & 1856536 & SM/J & ERV- $\beta 2 / E T n E R V 3$, Intron $13,+$ & Greatly reduced full length gene transcripts & [264] \\
\hline $\operatorname{Etn} 2^{S d}$ & 1857746 & $\begin{array}{l}\text { Danforth's posterior } \\
\text { duplication stock }\end{array}$ & ERV $\beta-2 / E T n E R V 3,12 \mathrm{~kb}$ upstream, + & $\begin{array}{l}\text { Overexpression of Ptf1a and two } \\
\text { neighboring genes, acts as an enhancer }\end{array}$ & [140-142] \\
\hline Nox3 het & 1856606 & GL/Le & Presumed ERVß-2/ETnERV3, Intron 12, + & $\begin{array}{l}\text { Transcripts show aberrant splicing from } \\
\text { Nox3 into retroviral element }\end{array}$ & {$[139,265]$} \\
\hline $\operatorname{Prph} 2^{R d 2}$ & 1856523 & O20/A & ERVß-2/ETnERV3, Exon 2,- & $\begin{array}{l}\text { Transcripts contain entire ERV, coding } \\
\text { sequence disruption }\end{array}$ & {$[266,267]$} \\
\hline$E d n r b^{5}$ & 1856148 & Fancy mice & ERV $\beta-4$, Intron 1, + & $\begin{array}{l}\text { Aberrant splicing and premature } \\
\text { polyadenylation }\end{array}$ & [268] \\
\hline$a$ & 1855937 & Fancy mice & $\begin{array}{l}\text { VL30, Intron 1, -; } \\
\text { ERVB-4 within VL30, + }\end{array}$ & $\begin{array}{l}\text { Smaller gene mRNA and levels } 8 \text { fold lower } \\
\text { than in wild-type. } \\
\text { Aberrant splicing and premature } \\
\text { termination within the ERV } \beta-4\end{array}$ & {$[22,143]$} \\
\hline $\operatorname{Dock} 7^{m}$ & 1856946 & JAX Dilute Brown & MERV-L, Exon 18, + & Frameshift and premature termination & {$[269,270]$} \\
\hline Fgf5 & 6147688 & ICR & Partial MTA MaLR, Intron 2, - & $\begin{array}{l}498 \mathrm{bp} \text { insertion is combined with } 9.3 \mathrm{~kb} \\
\text { deletion of exon } 3 \text { and flanking sequence, } \\
\text { no detectable transcripts }\end{array}$ & [158] \\
\hline Grmi ${ }^{c r v 4}$ & 3664783 & $\mathrm{BALB} / \mathrm{C} / \mathrm{Pas}$ & MERV-L solitary LTR, intron $4,+$ & $\begin{array}{l}\text { Aberrant splicing and premature } \\
\text { termination, transcripts contain LTR } \\
\text { sequence }\end{array}$ & [271] \\
\hline $\mathrm{NpCl}^{\mathrm{miN}}$ & 1857409 & $\mathrm{BALB} / \mathrm{C}$ & Partial MERV-L, Exon 9 & $\begin{array}{l}824 \text { bp partial and rearranged MERV-L com- } \\
\text { bined with } 703 \text { bp deletion. Transcripts } \\
\text { contain MERV-L sequence, decreased ex- } \\
\text { pression, premature truncation }\end{array}$ & [159] \\
\hline
\end{tabular}


locus has been mapped to a $9.4 \mathrm{Mb}$ region between markers D13Mit310 and D13Mit113 on chromosome 13 [122, 124]. Interestingly, this region includes a cluster of KRAB-ZFP (zinc finger protein) transcription factor genes. KRAB-ZFP genes are found in multiple clusters in the genome, are rapidly evolving and highly polymorphic in mice $[125,126]$ and some are involved in epigenetic silencing of ERVs [126]. Hence, it is tempting to speculate that the identity of mdac is such a gene.

\section{MLV insertion mutations}

The murine leukemia virus (MLV or MuLV) group is the most well characterized ERV group in the mouse and has caused seven documented spontaneous mutations (Fig. 1a,Table 3). MLV is also likely responsible for retrotransposing the non-autonomous VL30 ERV involved in the non-agouti mutation that will be discussed in the next section. MLVs are Class I elements, belonging to the gamma retrovirus genus, entered the mouse genome less that 1.5 million years ago and still contains infectious members [127]. MLV loci are highly insertionally polymorphic among strains [128, 129] with copy numbers of $\sim 20$ for xenotropic MLV and $\sim 40$ for polytropic MLV [9]. Ecotropic copies, i.e. those able to infect only mouse cells (and not those of other species) based on env protein recognition of a cellular receptor, are present in very few copies in various strains [127]. New germ line insertions appear to occur primarily through oocyte reinfection, rather than intracellular retrotransposition [130], which has likely kept MLV copy numbers low. Ever since it was first reported that exogenous MLV can integrate into the germ line [131], MLV and MLV-based vectors have been widely used for many applications including insertional mutagenesis screens, gene therapy and oncogene discovery [132-134].

All of the MLV mutation-causing insertions occur in gene introns and affect normal gene transcript processing to varying degrees (Table 3). The very first ERV-induced mutation to be described, over 35 years ago, was an MLV insertion causing the dilute coat color mutation $\left(M y o 5 a^{d}\right)$ in DBA/2J mice [135]. This mutation can revert due to homologous recombination between the $5^{\prime}$ and $3^{\prime}$ LTR of the full length provirus, leaving a solitary LTR at the locus [136]. Phenotypic reversion by this mechanism also occurs for the hairless mutation $\left(H r^{h r}\right)$, another of the first documented cases caused by an MLV insertion [137].

\section{Insertional mutations by other class II ERVs}

In addition to the ERVs discussed above, members of five other ERV groups have caused mouse mutations (Table 4). Like the IAP and ETn/MusD groups, two of the groups, ERV- $\beta 2$ and ERV- $\beta 4$, belong to Class II or the betaretrovirus genus as defined by pol homology
[14]. Both of these groups are heterogeneous and relatively low in copy number. The ERV- $\beta 2$ group includes mouse mammary tumor virus (MMTV) but the ERVs responsible for the four cases of mutations belong to a different ERV- $\beta 2$ cluster which has internal sequences annotated in Repbase [138] primarily as "ETnERV3" with LTRs annotated as "RLTR13A" [14]. The full ERV was not sequenced for the Nox $3^{\text {het }}$ mutation but we presume it to be an ERV- $\beta 2$ since the limited LTR sequence provided matched RLTR13A or RLTR13B [139]. For the other three ERV- $\beta 2$ cases in Table 4, their full sequences have been published and they are 96-99\% identical to each other with the major differences being internal deletions in the Agtpbp1 $1^{p c d-2 J}$ and Prph $2^{R d 2}$ elements with respect to the longer $E t n 2^{S d}$ ERV insertion (D. Mager, unpublished observations).

The above cases highlight the continual difficulties and confusion with ERV annotation. As an example, the ERV insertion causing the allele termed " $E t n 2$ " $d$ ", where the ERV likely acts as an enhancer, was reported to be an "ETn" element [140-142]. However, as discussed above, this is misleading since "ETnERV3" is a separate entity compared to the more well-known ETn/MusD group, an important distinction but likely generally overlooked. Interestingly, when the reference $\mathrm{C} 57 \mathrm{Bl} / 6$ genome was analyzed in 2004, less than 15 ERV loci falling into the ERV- $\beta 2$ group were found and none were fully coding competent [14]. Moreover, all of the ERV- $\beta 2$ s discussed above also lack full open reading frames. Nonetheless, the presence of these elements at sites of new mutations in other strains suggests such strains have or had coding-competent members to provide proteins in trans, allowing retrotransposition of defective elements. The strains in which the ERV- $\beta 2$ mutations arose (Table 4) do not share close relationships so the origin of any active autonomous copies is unknown.

The ERV- $\beta 4$ group [14] has been involved in two known mutations and both occurred in old "fancy mice" (Table $4)$. One of these mutations $\left(E d n r b^{s}\right)$ was caused by insertion of a $5 \mathrm{~kb}$ non-coding competent element whose internal sequence is classified as "ERV- $\beta 4$ _1B-I (internal)" in Repbase [138] but half of the sequence in the middle of the element actually lacks homology to retroviruses (unpublished observations). Fifteen to 20 sequences closely related to the $E d n r b^{s}$ element exist in the C57BL/6 reference genome and, since they contain LTRs and parts of the $5^{\prime}$ and $3^{\prime}$ internal sequences highly similar to the ERV- $\beta 4$ element discussed below, it is likely that this small non-autonomous group has amplified using retroviral proteins provided by coding competent ERV- $\beta 4$ elements.

The other mutation case involving an ERV- $\beta 4$ is complex. The $a$ (non-agouti) allele of the agout $i$ gene is one of many agouti alleles affecting coat color [143], including four caused by IAP insertions (Table 1). The $a$ allele 


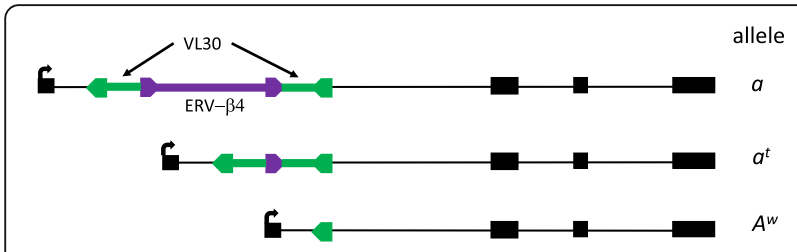

Fig. 3 Three alleles of the agouti gene involving ERV insertions. The a (non-agouti) mutant allele is fixed in the reference strain C57BL/6. It involves a VL30 ERV and an ERV- $\beta 4$ inserted within it. Partial phenotypic reversion of non-agouti occurs frequently. The $a^{t}$ (black and tan) allele results from recombination between the LTRs of the ERV- $\beta 4$. The $A^{w}$ (white-bellied agouti) allele results from recombination between the VL30 LTRs. See text for references. Gene structure in black is shown to very rough scale. Green arrows and lines are the LTRs and internal VL30 sequences. Purple arrows and line depict the ERV- $\beta 4$

is fixed in the reference strain $\mathrm{C} 57 \mathrm{BL} / 6$ and is responsible for its black coat color. Molecular characterization of non-agouti in the early 1990s revealed that it was caused by a $5.5 \mathrm{~kb}$ VL30 ERV insertion in the first intron of the agouti gene with another reported $\sim 5.5 \mathrm{~kb}$ segment flanked by $526 \mathrm{bp}$ direct repeats found within the VL30 [22, 143]. Our perusal of the fully sequenced reference C57BL/6 genome shows that the sequence within the VL30 is $\sim 9.3 \mathrm{~kb}$. The mutation is reported to be caused by a VL30, which belongs to a well-studied medium repetitive non-autonomous Class I ERV group that is co-packaged with MLV, allowing its retrotransposition $[144,145]$. Although VL30 is insertionally polymorphic among inbred strains [17], this is the only reported VL30-caused mutation. The nature of the insertion within the VL30 was not known at the time of analysis, but the C57BL/6 sequence shows it to be an ERV- $\beta 4$ (coordinates of the full $\sim 14.7 \mathrm{~kb}$ VL30/ERV- $\beta 4$ insertion are chr2:155014951$155,029,651$, GRCm38/mm10). Hence two ERV insertion events contributed to the non-agouti mutation, a VL30 insertion followed by insertion of an ERV- $\beta 4$ within it (Fig. 3). The non-agouti a allele reverts at a high frequency to "black and $\tan "\left(a^{t}\right)$ or white-bellied agouti $\left(A^{w}\right)[22,143]$. Molecular analyses by Bulman et al. showed that the $a^{t}$ allele contains the VL30 element with a single ERV- $\beta 4$ LTR and the $A^{w}$ allele contain just one VL30 LTR [22](Fig. 3). Therefore, normal agouti gene expression can be partly restored by homologous recombination between the LTRs of the VL30 or the ERV- $\beta 4$, as has also been observed for MLV mutations (discussed above). Notably, the ERV- $\beta 4$ element involved in the non-agouti $a$ allele is the only fully coding competent ERV- $\beta 4$ copy in the C57BL/6 genome [14].

\section{Insertions by MERV-L/MaLR elements}

The Class III MERV-L LTR retrotransposon group has also caused a few mutations (lower part of Table 4). MERV-L is a large, recently amplified group in the mouse with coding competent members but lacking an env gene [146-148]. These retrotransposons are highly expressed in the 2-cell embryo [79, 149], create viral-like particles [150] and $\sim 700$ full length or near full length elements exist in the reference C57BL/6 genome [148]. Therefore, the fact that there are only three reported germ line mutations caused by MERV-L insertions is somewhat paradoxical. Despite the high transcript level and particle formation by MERV-L at the two cell stage, it appears that any fully retrotranspositionally competent members are very rare or effectively blocked from completing retrotransposition by host defense mechanisms. Indeed, MERV-L elements amplified in two major bursts in mouse evolution, approximately 2 and 10 million years ago [147] and it is possible that host genetic adaptations as a result of a host-virus "arms race" [151] have effectively repressed further MERV-L expansion. Interestingly, MERV-L and associated MT MaLR LTRs have been co-opted to drive expression of genes and other transcripts involved in early embryogenesis and zygotic genome activation [79, 152-154] and there is evidence that MERV-L expression is important for embryonic development [155].

Insertion of a partial MTA MaLR element, belonging to a large young group of non-autonomous retrotransposons related to MERV-L $[15,156]$, and also highly expressed in early embryogenesis [153, 157], has contributed to a mutation in the Fgf5 gene [158]. However, this case and the MERV-L insertion causing the $N p c 1^{m 1 N}$ mutation [159] are both partial elements and are coupled with genomic deletions, so the order of events resulting in these mutations is unclear. It is noteworthy that two of the four cases associated with Class III MERV-L/MaLR mutagenic insertions involve rearrangements of the ERV itself as well as genomic deletions. Interestingly, MaLR elements are associated with formation of independent hypervariable minisatellite sequence arrays in both human and mouse [160, 161], suggesting that these elements may foster genomic recombination and rearrangements.

\section{LINE1 insertion mutations}

Our literature and MGI database search resulted in a list of 12 germ line mutations caused by $\mathrm{L} 1$ insertions (Table 5, Fig. 1). Of the 11 where the length and/or sequence of the insertion was published, five are full length (or nearly full length) and six are partial elements, with the shortest being only $81 \mathrm{bp}$. All five full length insertions belong to the L1MdTf family, subtypes I or II, which are among the youngest L1 subfamilies, each with 
Table 5 L1 Insertions

\begin{tabular}{|c|c|c|c|c|c|}
\hline Mutation & $M G I \mid D^{a}$ & Strain of origin & L1 length, location and orientation ${ }^{b}$ & Mutational mechanisms or effects & References \\
\hline$\overline{A t p 7 a^{M o-c a}}$ & 2387450 & unknown & 81 bp L1, exon 10,- & $\begin{array}{l}\text { Aberrant splicing causing in-frame loss } \\
\text { of } 10 \text { amino acids }\end{array}$ & {$[272]$} \\
\hline Dabi $1^{\text {yot }}$ & 1857750 & Chimera of 129 and C57BL/6 & Rearranged partial L1MdTf, intron & $\begin{array}{l}\text { Partial gene deletion and atypical } \\
962 \text { bp L1 insertion }\end{array}$ & [273] \\
\hline Frem $1^{\text {heb }}$ & 1856897 & $\mathrm{AKR} / \mathrm{J}$ & Unknown length L1, exon $17,+$ & Transcript and protein truncation & {$[274]$} \\
\hline$G l r b^{s p a}$ & 1856363 & Random-bred stock & Full length L1MdTf_I intron 6, - & $\begin{array}{l}\text { Reduced expression of normal transcript } \\
\text { and exon skipping }\end{array}$ & {$[275-277]$} \\
\hline Lama2 $^{d y-P a s}$ & 6220701 & Non-inbred Agouti & $\begin{array}{l}\text { Nearly full length L1MdTf_II and } \\
3^{\prime} \text { transduction, intron } 34,_{+}\end{array}$ & $\begin{array}{l}\text { Transcript contains internal IAP sequence, } \\
\text { Truncated protein. } \\
\text { L1-mediated retrotransposition event } \\
\text { involving an L1 and } 3^{\prime} \text { transduced IAP LTR }\end{array}$ & [163] \\
\hline Lyst $^{b g}$ & 1855968 & C3H/RI X 101/R1 (from radiation exp.) & $1.1 \mathrm{~kb} 5^{\prime}$ truncated $\mathrm{L} 1$, intron, + & $\begin{array}{l}\text { Two alternatively spliced transcripts } \\
\text { containing } L 1 \text { sequence results in two } \\
\text { truncated forms of the protein }\end{array}$ & {$[278,279]$} \\
\hline Mitt ${ }^{m i-b w}$ & 1856089 & $\mathrm{C} 3 \mathrm{H}$ & Full length L1MdTf_II, intron 3, + & $\begin{array}{l}\text { Decreased expression and exon skipping } \\
\text { of two isoforms and abolished expression } \\
\text { of the third isoform }\end{array}$ & {$[280]$} \\
\hline$N r 2 e 3^{r d 7}$ & 1859180 & 77-2C2a-special- JAX & $\begin{array}{l}\text { Full length L1MdTf_I with } 28 \text { bp } \\
5^{\prime} \text { transduction, exon } 5,-\end{array}$ & $\begin{array}{l}\text { Accumulation of incompletely spliced } \\
\text { transcripts. }\end{array}$ & [162] \\
\hline Pde6c ${ }^{\text {cpfli }}$ & 2657247 & Recom. Inbred CXB1/ByJ & $\begin{array}{l}1.5 \mathrm{~kb} \text { insertion of truncated L1 \& } \\
\text { likely } 3^{\prime} \text { transduction, Intron } 4,-\end{array}$ & $\begin{array}{l}\text { Aberrant splicing within inserted sequence } \\
\text { causes inclusion of extra } 116 \text { bp exon and } \\
\text { frame shift. }\end{array}$ & {$[164]$} \\
\hline Reln ${ }^{r l-O r l}$ & 1856416 & $\mathrm{BALB} / \mathrm{C}$ & Full length L1MdTf_I exon 59, + & $\begin{array}{l}220 \text { bp deletion in mRNA due to skipping } \\
\text { of exon containing } L 1\end{array}$ & {$[281]$} \\
\hline Scn8a $a^{\text {med }}$ & 1856078 & $\mathrm{PCT}$ & 180 bp 5' truncated L1, Exon 2,- & Skipping of exon containing $L 1$, loss of functional protein & {$[282]$} \\
\hline$T t n^{m d m}$ & 1856953 & C57BL/6J & $2.4 \mathrm{~kb} L 1$, exon $3,+$ & $\begin{array}{l}779 \text { bp gene deletion and } L 1 \text { insertion causes } \\
\text { exon loss or chimeric transcripts }\end{array}$ & {$[283]$} \\
\hline
\end{tabular}

IID number in Mouse Genome Informatics (MGI) database

$\mathrm{b}_{-}=$antisense, $+=$sense, $?=$ orientation unknown

over 1000 full length elements in C57BL/6 [34]. (Note that some revisions and updates to L1 subfamily classification and nomenclature have occurred [34]). In two cases, the source L1 element could be identified due to inclusion of flanking transduced sequence at the new insertion site. In the $\mathrm{Nr}^{2} \mathrm{e} 3 \mathrm{rd} \mathrm{d}^{7}$ mutant allele, the L1 insertion includes $28 \mathrm{bp}$ of $5^{\prime}$ transduced sequence, allowing the source element to be traced to the L1 at chr4:21650298-21,656,544 (GRCm38/mm10) [162]. The other case $\left(\right.$ Lama $\left.2^{d y-P a s}\right)$ is interesting in that it involves an IAP LTR and an L1 [163]. While not reported as an L1 3' transduction event in the original paper [163], our

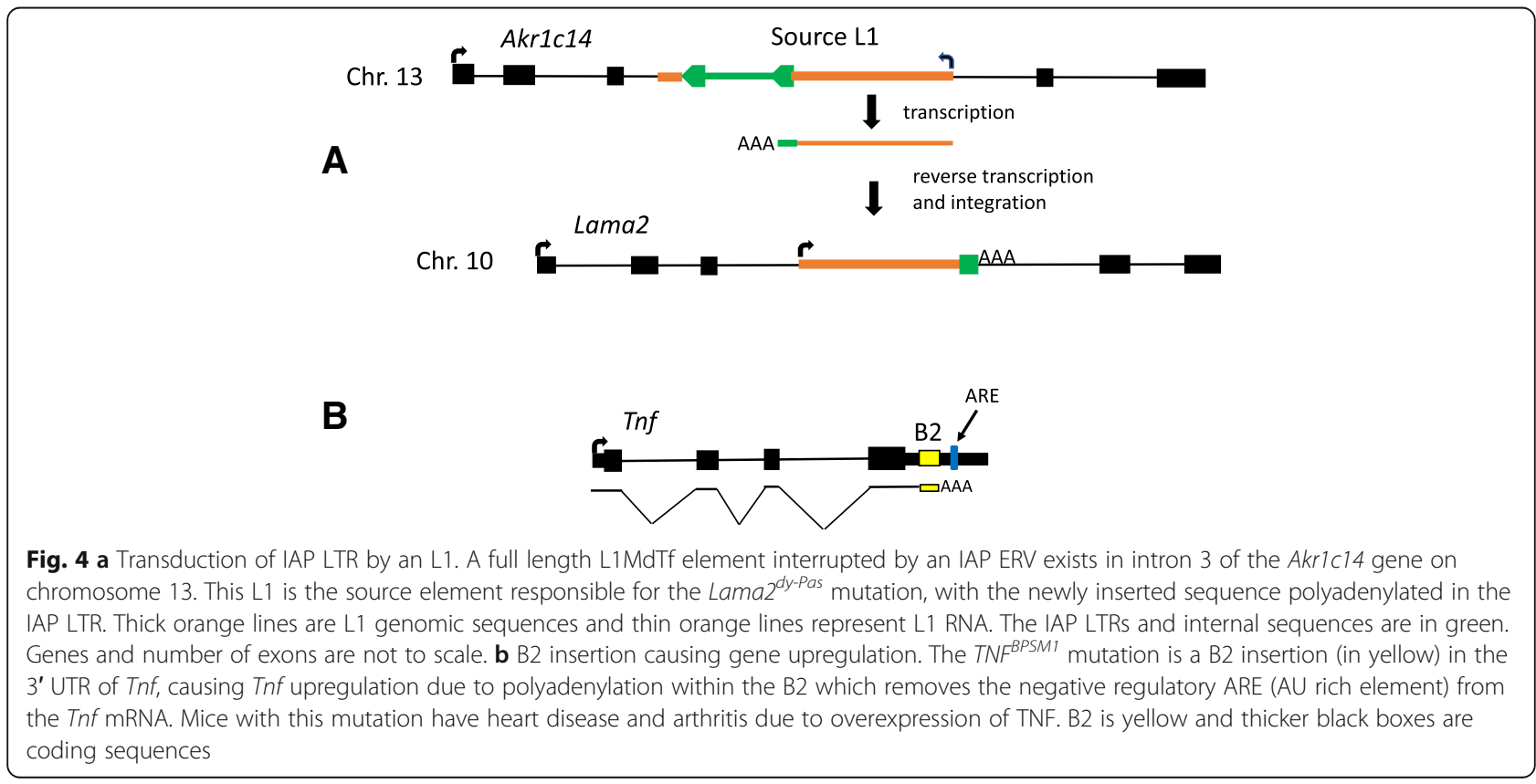


perusal of the inserted sequence (Genbank accession AJ277888) revealed that the L1 has transduced the IAP LTR, with the inserted sequence polyadenylated within the 5 ' LTR (Fig. 4a). The source L1 has a $3.7 \mathrm{~kb}$ partly deleted IAP element inserted within it, so that $\sim 700 \mathrm{bp}$ of the 3' end of the L1 occurs on the other side of the IAP (coordinates of the source L1/IAP are chr13:4065522-4,076,041, GRCm38/mm10). Another L1 insertion $\left(P d e 6 c^{c p f l}\right)$, which occurred in a recombinant inbred strain established from a $\mathrm{C} 57 \mathrm{Bl} / 6$ and $\mathrm{BALB} / \mathrm{c}$ intercross, has the classical molecular structure of a 3' transduction event [164]. However, there is no L1 element in either the sequenced $\mathrm{C} 57 \mathrm{BL} / 6$ or $\mathrm{BALB} / \mathrm{c}$ genomes at the original location of the transduced sequence (unpublished observations), which occurs in an intron of the Diaph2 gene [164]. Therefore, the simplest explanation is that an L1 inserted in the Diaph2 gene in the particular mouse colony being used and then retrotransposed again, creating the $P d e 6 c^{c p f l 1}$ allele.

L1 insertions have occurred in a variety of genetic backgrounds, with no evident strain bias. The mutational effects of these insertions are as expected, with intronic L1s affecting splicing and exonic cases physically disrupting the coding sequence. Interestingly of the 12 L1 cases, half occur in gene exons and half in introns (Table 5), which is more skewed toward exons compared to the ERV insertions discussed above (Tables 1-4). It is a reasonable assumption that truncated (and hence shorter) L1 insertions might be less likely to affect transcript processing if inserted in an intron. (See also discussion of SINE insertions below). Indeed, the two shortest L1 insertions of 81 and $180 \mathrm{bp}$ both occur in exons (Table 5). However, two of the five full length L1s, which are similar to size to ERVs, also occur in exons.

\section{SINE and other LINE1-mediated insertion mutations} Members of two mouse SINE families, B1 and B2, have caused documented mutations (Table 6). Also included in this Table is a presumed L1-mediated insertion of Cenpw cDNA into an exon of Pocla [165]. It is noteworthy that, although higher numbers of B1 elements have accumulated during mouse evolution [1], seven of the eight mutation-causing SINE insertions are B2 with no evident strain bias (Table 6, Fig. 1c). In accord with the preponderance of B2- over B1-caused mutations, retrotransposition assays in vitro showed a higher retrotransposition rate for $\mathrm{B} 2$ compared to $\mathrm{B} 1$, although the assays were conducted in human cells [58]. It is possible that B2 is currently the more active family in inbred strains, contains some members more efficient at utilizing the L1 retrotransposition machinery and/or are more transcriptionally active in the germ line. Interestingly, Dewannieux et al. [58] found that most B1 elements have a nucleotide mutation compared to Alu elements and 7SL RNA (from which both B1 and Alu were derived) and noted that this highly conserved nucleotide is critical for 7SL RNA interaction with SRP9/14 proteins [166]. As has been shown for Alu elements [167], this interaction is expected to enhance L1-mediated retrotransposition of B1. Indeed, replacement of this nucleotide in several tested B1 elements resulted in a much higher retrotransposition rate in culture [58]. Therefore, B1 elements harboring this mutation have become the most prevalent in the genome despite the fact that the mutation lowered their ability to retrotranspose. Although the evolutionary trajectory resulting in B1 prevalence is unknown, it has been suggested that, during mouse evolution, such B1 elements have been selectively retained to minimize harm to the host [58].

Table 6 SINEs and other L1-mediated insertions

\begin{tabular}{|c|c|c|c|c|c|}
\hline Mutation & $M G \mid D^{a}$ & Strain of origin & $\begin{array}{l}\text { Insertion type, } \\
\text { location, and } \\
\text { orientation }^{\mathrm{b}}\end{array}$ & Mutational mechanisms or effects & $\overline{\text { References }}$ \\
\hline Atcay $^{i j}$ & 1856574 & Bagg albino & B1, exon 4, + & B1 insertion causes protein truncation and rare exon skipping & {$[187,284]$} \\
\hline $\mathrm{Comt}^{B 2 i}$ & 4819952 & $\begin{array}{l}\text { Strain variant, likely origin in } \\
\text { Lathrop stock }\end{array}$ & $\mathrm{B} 2,3^{\prime} \cup \mathrm{TR},+$ & $\begin{array}{l}\text { Premature polyadenylation leads to shortened } 3^{\prime} U T R \text { and increased } \\
\text { protein expression. Associated with behavioral difference. }\end{array}$ & {$[170,171]$} \\
\hline$G_{d} d m a 3^{D f l}$ & 2385837 & $\mathrm{BALB} / \mathrm{C}$ & B2, exon 7,+ & B2 causes premature termination, transcript includes B2 sequence & {$[285]$} \\
\hline Ndufs $4^{f k y}$ & 4942335 & $\begin{array}{l}\text { Male Dnmt3L +/- x female } \\
\text { transgenic RIP-mOVA C } 57 \mathrm{BL} / 6\end{array}$ & B2, exon $3,+$ & B2 insertion causes exon skipping and premature termination & {$[286]$} \\
\hline $\operatorname{Nrcam}^{m i s}$ & 5444298 & B6.129P2-Cnr2tm1Dgen/J & B2, exon $26,-$ & Aberrant splicing and premature termination & {$[287]$} \\
\hline Pocla cha & 2135614 & DBA.B6-A ${ }^{\text {hvy }} / \mathrm{a} \times \mathrm{DBA} / 2 \mathrm{~J}$ & Gene cDNA, exon 8, & $\begin{array}{l}\mathrm{L} 1 \text { mediated insertion of Cenpw cDNA in exon } 8 \text {. Exon } 8 \text { is skipped, } \\
\text { reading frame preserved }\end{array}$ & {$[165]$} \\
\hline $\operatorname{Ptpn}_{B 2}^{m e-}$ & 4947257 & $\mathrm{BALB} / \mathrm{C}$ & B2, exon $6,+$ & $\begin{array}{l}\text { Replacement of exon } 6 \text { sequence with B2 sequence, reading frame } \\
\text { preserved }\end{array}$ & {$[288]$} \\
\hline Slc27a $4^{\text {wrfr }}$ & 2445864 & $(129 \times 1 / S v J \times 129 S 1 / S v) F 1$ & B2, exon $3,-$ & Coding sequence disruption, no mRNA or protein detected & {$[289]$} \\
\hline Tnf $f^{\beta p m} 1$ & 5795894 & $\mathrm{C} 57 \mathrm{BL} / 6$ & $\mathrm{~B} 2,3^{\prime} \mathrm{UTR},+$ & $\begin{array}{l}\text { Premature polyadenylation leads to shortened 3'UTR and gene } \\
\text { overexpression }\end{array}$ & {$[172]$} \\
\hline
\end{tabular}

${ }^{a}$ ID number in Mouse Genome Informatics (MGI) database

$\mathrm{b}_{-}=$antisense, $+=$sense, $?=$ orientation unknown 
Unlike the ERV mutation-causing insertions, where most cases occur in introns (Tables 1-4), all such mouse SINE insertions have occurred in exons (Table 6), which represent a much smaller genomic space. The marked bias toward exonic insertions also occurs for disease-causing Alus [4]. This could simply be due to the fact that SINEs are shorter and therefore new insertions are much less likely to significantly disrupt gene expression if inserted into an intron. Indeed, although SINEs, particularly Alus, can cause alternative splicing and exonization [168], both human and mouse SINEs are relatively enriched in introns [169] and show less evidence of selection against intronic insertions compared to ERVs or L1s [68].

As is the case for mutation-causing human Alu insertions [4], most of the mouse SINE insertions directly disrupt the gene's coding sequence, causing exon skipping, protein ablation, truncations or amino acid replacements (Table 6). However, in the Comt ${ }^{B 2 i}$ allele, which is a strain variant present in $\mathrm{C} 57 \mathrm{BL} / 6$ and a few other strains $[170,171]$ and in the Tnf $f^{\text {Bpsm1 }}$ mutation [172], a B2 element inserted into the 3' UTR causes gene upregulation, which underlies the phenotype. This effect is due to a shortened 3' UTR caused by premature polyadenylation within the $\mathrm{B} 2$ and a resultant replacement or disruption of negative regulatory motifs within the UTR, which has been directly shown for $T n f^{B p s m 1}$ [172] (Fig. 4b).

\section{Concluding remarks}

This review has provided a comprehensive catalog and discussion of mouse mutations caused by insertions of ERVs, LINEs and SINEs. It is clear that, among these TE types, ERV insertion mutations are the most prevalent (Fig. 1a). Through an accounting of all independent spontaneous mutant alleles in mouse, it was previously estimated that ERV insertions comprise 10-12\% of all published spontaneous mutations $[1,20]$. Another previous report estimated that L1 insertions account for 2$3 \%$ of mouse mutations [173], suggesting a relative ratio of ERV to L1 insertion mutations of 4 to 6 . Our updated numbers (94 ERV cases and 12 L1 cases) reveal a somewhat higher ratio of approximately eight. If the nine SINE insertion cases reported here are included, the ratio of ERV to "L1-mediated" insertion mutations is $~ 4.5$.

Since both human and mouse have active L1s, we can attempt to compare relative L1 recent "activity" based solely on the number of documented mutations due to L1 insertions. Both bioinformatics and functional studies [31-33] suggest that the typical inbred mouse genome harbors roughly 20-30 times more retrotranspositionally competent L1s compared to human ( 3000 versus 100-150). All else being equal, one might then expect the frequency of L1 insertional mutations to be 20-30 times higher in mouse. Recent reviews on retrotransposons in human disease report 22 cases of L1 insertions causing heritable mutations/diseases [4, 174]. To put these numbers in context, it should be remembered that many more mutations have been described in human compared to mouse. The Human Gene Mutation Database [175], lists $\sim 240,000$ entries as of January 2019. In contrast, the MGI database [65], lists only 2100 spontaneous mutant alleles as of the same date, and many of these are non-independent entries or revertant cases. While comparing such overall numbers is fraught with caveats, they are however still useful to illustrate the point that the mouse "mutational space" is vastly understudied compared to human. Hence, the relatively low number of 12 mouse L1 mutations (when compared to the number of human L1 mutations) is not unexpected but rather simply appears low when viewed against the high numbers of ERV mutations. Indeed this number is approximately in line with expectations when compared to human, given the much higher number of active L1s but much lower numbers of all characterized mutations in mouse.

In considering L1-mediated insertion mutations as a fraction of all mutations, the numbers reported here suggest a frequency of $3-5 \%$ in mouse, building on the previous L1 estimate of $2-3 \%$ [173] and including the SINE cases. There have been various estimates for the frequency of L1-mediated mutations in human, with an early estimate of 1 in 600 (0.16\%) reported by Kazazian [176]. A more recent study of the spectrum of mutations in a single gene found that TE insertions caused $0.4 \%$ of all mutations in NF-1 [177], although it is unclear if this figure can be extrapolated to all genes. In any case, these estimates suggest that the contribution of L1 activity to overall mutational burden is at least 10 fold higher in mouse.

Concerning mouse ERVs, there are several distinct ERV groups currently able to retrotranspose at least in some strains, including the low copy number and poorly characterized ERV- $\beta 2$ and ERV- $\beta 4$ groups [14], previously not known to be active. Unpublished transcriptome analysis indicates that expression of both these groups is readily detectable in early embryonic stages (Julie Brind'Amour and Matt Lorincz, personal communication) but little else is known about them. The fact that new insertions have been found for such low copy number ERV groups indicates they are still mutagenic in some strains and worthy of further investigation.

Another point worth emphasizing is that, although IAP ERVs are young and have accumulated to high copy numbers in inbred strains, they perhaps do not deserve the often used designation as the currently "most active" group of mouse ERVs. This is likely true only in $\mathrm{C} 3 \mathrm{H}$ mice and, if this strain is removed from consideration, a modest seven IAP-caused mutations can be documented 
to have occurred in strains unrelated to $\mathrm{C} 3 \mathrm{H}$ (Table 1,। Fig. 1b). This number of mutations places IAP recent "activity" more on a par with the low copy number MLV and ERV- $\beta 2$ groups and suggests that the genomic expansion of IAPs in most strains has largely ceased, likely due to host defense mechanisms [86, 151, 178-180] gaining the upper hand. Exclusive of the $\mathrm{C} 3 \mathrm{H}$ strain, the ETn/MusD group accounts for the most mutagenic ERV insertions. One possible reason for the high IAP-induced mutations in $\mathrm{C} 3 \mathrm{H}$ mice could be a slight relaxation of repression in the germ line, so it would seem prudent for investigators to consider including this strain in studies to investigate the regulation of IAPs. This extreme strain bias for IAP activity also illustrates the difficulty in attempting to compare de novo TE insertion mutation rates in the "outbred" human population with those in the artificial environment of inbred mice. Nonetheless, the primary difference between human and mouse in terms of TE-induced insertional mutations is clearly the lack of ongoing ERV activity in modern humans.

\section{Abbreviations}

Dac: Dactylaplasia; ERV: Endogenous retrovirus; ETn: Early transposon; IAP: Intracisternal A type particle; JAX: The Jackson Laboratory; L1: LINE-1 family; LINE: Long interspersed element; LTR: Long terminal repeat; MaLR: Mammalian apparent LTR retrotransposon; MLV: Murine leukemia virus; ORF: Open reading frame; SINE: Short interspersed element; TE: Transposable element

\section{Acknowledgements}

We thank Rita Rebollo for help with figures and for making suggestions on this review. We also thank Diana Juriloff for advice on mouse history and Jonathan Stoye for reading the MLV section. We apologize to authors if we failed to mention relevant work.

\section{Funding}

Relevant work in the Mager lab is currently funded by the Natural Sciences and Engineering Council of Canada. V. Belancio is funded by $\mathrm{NIH}$ grants R21AG055387 and R01AG057597 and the Brown Foundation.

\section{Availability of data and materials}

This is a review article. Data sharing not applicable to this article as no datasets were generated or analyzed during the current study.

\section{Authors' contributions}

LG and DLM compiled data and VLP and DLM wrote the manuscript. All authors read and approved the final manuscript.

Ethics approval and consent to participate

Not applicable. This is a review article on mouse.

\section{Consent for publication}

Not applicable

\section{Competing interests}

The authors declare that they have no competing interests.

\section{Publisher's Note}

Springer Nature remains neutral with regard to jurisdictional claims in published maps and institutional affiliations.

\section{Author details}

${ }^{1}$ Terry Fox Laboratory, BC Cancer and Department of Medical Genetics,

University of British Columbia, V5Z1L3, Vancouver, BC, Canada. ${ }^{2}$ Department of Structural and Cellular Biology, Tulane University School of Medicine,

Tulane Cancer Center, Tulane Center for Aging, New Orleans, LA 70112, USA.

Received: 29 January 2019 Accepted: 1 April 2019

Published online: 13 April 2019

\section{References}

1. Consortium MGS. Initial sequencing and comparative analysis of the mouse genome. Nature. 2002;420:520-62.

2. Belancio VP, Hedges DJ, Deininger P. Mammalian non-LTR retrotransposons: for better or worse, in sickness and in health. Genome Res. 2008;18(3):343-58.

3. Richardson SR, Doucet AJ, Kopera HC, Moldovan JB, Garcia-Perez JL, Moran $\mathrm{JV}$. The Influence of LINE-1 and SINE Retrotransposons on Mammalian Genomes. Microbiol Spectr. 2014;3(2):Mdna3-0061-2014.

4. Hancks DC, Kazazian HH. Roles for retrotransposon insertions in human disease. Mob DNA. 2016;7(1):9.

5. Kazazian HH, Moran JV. Mobile DNA in health and disease. N Engl J Med. 2017;377(4):361-70.

6. Mager DL, Stoye JP. Mammalian Endogenous Retroviruses. Microbiol Spectr. 2014:3(1):MDA3-0009-2014

7. Johnson WE. Endogenous retroviruses in the genomics era. Annu Rev Virol. 2015;2(1):135-59.

8. Stoye JP. Studies of endogenous retroviruses reveal a continuing evolutionary saga. Nat Rev Microbiol. 2012:10(6):395-406.

9. Stocking C, Kozak CA. Murine endogenous retroviruses. Cell Mol Life Sci. 2008:65(21):3383-98.

10. Varmus HE. Form and function of retroviral proviruses. Science. 1982; 216(4548):812-20.

11. Thompson Peter J, Macfarlan Todd S, Lorincz MC. Long terminal repeats: from parasitic elements to building blocks of the transcriptional regulatory repertoire. Mol Cell. 2016;62(5):766-76.

12. Rebollo R, Romanish MT, Mager DL. Transposable elements: an abundant and natural source of regulatory sequences for host genes. Annu Rev Genet. 2012;46:21-42.

13. Chuong EB, Elde NC, Feschotte $C$. Regulatory activities of transposable elements: from conflicts to benefits. Nat Rev Genet. 2017;18:71-86.

14. Baillie GJ, van de Lagemaat LN, Baust C, Mager DL. Multiple groups of endogenous betaretroviruses in mice, rats, and other mammals. J Virol. 2004;78(11):5784-98

15. McCarthy EM, McDonald JF. Long terminal repeat retrotransposons of Mus musculus. Genome Biol. 2004;5(3):R14.

16. Belshaw R, Watson J, Katzourakis A, Howe A, Woolven-Allen J, Burt A, et al. Rate of Recombinational deletion among human endogenous retroviruses. J Virol. 2007:81(17):9437-42.

17. Nellaker C, Keane T, Yalcin B, Wong K, Agam A, Belgard TG, et al. The genomic landscape shaped by selection on transposable elements across 18 mouse strains. Genome Biol. 2012;13(6):R45.

18. Jern P, Coffin JM. Effects of retroviruses on host genome function. Annu Rev Genet. 2008;42:709-32.

19. Magiorkinis G, Blanco-Melo D, Belshaw R. The decline of human endogenous retroviruses: extinction and survival. Retrovirology. 2015;12:8.

20. Maksakova IA, Romanish MT, Gagnier L, Dunn CA, van de Lagemaat LN, Mager DL. Retroviral elements and their hosts: insertional mutagenesis in the mouse germ line. PLoS Genet. 2006;2(1):e2.

21. Adachi M, Watanabe-Fukunaga R, Nagata S. Aberrant transcription caused by the insertion of an early transposable element in an intron of the Fas antigen gene of Ipr mice. Proc Natl Acad Sci. 1993;90(5):1756-60.

22. Bultman SJ, Klebig ML, Michaud EJ, Sweet HO, Davisson MT, Woychik RP. Molecular analysis of reverse mutations from nonagouti (a) to black-and-tan (a(t)) and white-bellied agouti (aw) reveals alternative forms of agouti transcripts. Genes Dev. 1994;8(4):481-90.

23. Moon BC, Friedman JM. The molecular basis of the obese mutation in ob2JMice. Genomics. 1997:42(1):152-6.

24. Begoña Cachón-González M, San-José I, Cano A, Antonio Vega J, García N, Freeman $T$, et al. The hairless gene of the mouse: relationship of phenotypic effects with expression profile and genotype. Dev Dyn. 1999;216(2):113-26.

25. Johnson KR, Cook SA, Erway LC, Matthews AN, Sanford LP, Paradies NE, et al. Inner ear and kidney anomalies caused by IAP insertion in an intron of the Eyal gene in a mouse model of BOR syndrome. Hum Mol Genet. 1999;8(4):645-53.

26. Lander ES, Linton LM, Birren B, Nusbaum C, Zody MC, Baldwin J, et al. Initial sequencing and analysis of the human genome. Nature. 2001;409(6822):860-921. 
27. Dombroski BA, Feng Q, Mathias SL, Sassaman DM, Scott AF, Kazazian HH Jr, et al. An in vivo assay for the reverse transcriptase of human retrotransposon L1 in Saccharomyces cerevisiae. Mol Cell Biol. 1994;14(7):4485-92.

28. Moran JV, Holmes SE, Naas TP, DeBerardinis RJ, Boeke JD, Kazazian HH Jr. High frequency retrotransposition in cultured mammalian cells. Cell. 1996;87(5):917-27.

29. Feng Q, Moran JV, Kazazian HH Jr, Boeke JD. Human L1 retrotransposon encodes a conserved endonuclease required for retrotransposition. Cell. 1996:87(5):905-16

30. Clements AP, Singer MF. The human LINE-1 reverse transcriptase:effect of deletions outside the common reverse transcriptase domain. Nucleic Acids Res. 1998;26(15):3528-35.

31. Penzkofer $T$, Jager M, Figlerowicz M, Badge R, Mundlos $S$, Robinson PN, et al. L1Base 2: more retrotransposition-active LINE-1s, more mammalian genomes. Nucleic Acids Res. 2017;45(D1):D68-73.

32. Goodier JL, Ostertag EM, Du K, Kazazian HH Jr. A novel active L1 retrotransposon subfamily in the mouse. Genome Res. 2001;11(10):1677-85.

33. Brouha B, Schustak J, Badge RM, Lutz-Prigge S, Farley AH, Moran JV, et al. Hot L1s account for the bulk of retrotransposition in the human population. Proc Natl Acad Sci U S A. 2003;100(9):5280-5.

34. Sookdeo A, Hepp CM, McClure MA, Boissinot S. Revisiting the evolution of mouse LINE-1 in the genomic era. Mob DNA. 2013;4(1):3.

35. Akagi K, Li J, Stephens RM, Volfovsky N, Symer DE. Extensive variation between inbred mouse strains due to endogenous $L 1$ retrotransposition. Genome Res. 2008;18(6):869-80.

36. Adey NB, Schichman SA, Graham DK, Peterson SN, Edgell MH, Hutchison CA 3rd. Rodent $L 1$ evolution has been driven by a single dominant lineage that has repeatedly acquired new transcriptional regulatory sequences. Mol Biol Evol. 1994;11(5):778-89.

37. Severynse DM, Hutchison CA 3rd, Edgell MH. Identification of transcriptional regulatory activity within the $5^{\prime}$ A-type monomer sequence of the mouse LINE-1 retroposon. Mamm Genome. 1992;2(1):41-50.

38. DeBerardinis RJ, Kazazian HH Jr. Analysis of the promoter from an expanding mouse retrotransposon subfamily. Genomics. 1999;56(3):317-23.

39. Han JS. Non-long terminal repeat (non-LTR) retrotransposons: mechanisms, recent developments, and unanswered questions. Mob DNA. 2010;1(1):15.

40. Perepelitsa-Belancio V, Deininger P. RNA truncation by premature polyadenylation attenuates human mobile element activity. Nat Genet. 2003;35(4):363-6.

41. Han JS, Szak ST, Boeke JD. Transcriptional disruption by the L1 retrotransposon and implications for mammalian transcriptomes. Nature. 2004;429(6989):268-74.

42. Belancio VP, Hedges DJ, Deininger P. LINE-1 RNA splicing and influences on mammalian gene expression. Nucleic Acids Res. 2006;34(5):1512-21.

43. Wheelan SJ, Aizawa Y, Han JS, Boeke JD. Gene-breaking: a new paradigm for human retrotransposon-mediated gene evolution. Genome Res. 2005; 15(8):1073-8.

44. Matlik K, Redik K, Speek M. L1 antisense promoter drives tissue-specific transcription of human genes. J Biomed Biotechnol. 2006;2006(1):71753.

45. van de Lagemaat LN, Medstrand P, Mager DL. Multiple effects govern endogenous retrovirus survival patterns in human gene introns. Genome Biol. 2006;7(9):R86.

46. Farley AH, Luning Prak ET, Kazazian HH Jr. More active human L1 retrotransposons produce longer insertions. Nucleic Acids Res. 2004;32(2):502-10.

47. Gasior SL, Roy-Engel AM, Deininger PL. ERCC1/XPF limits L1 retrotransposition. DNA Repair. 2008;7(6):983-9.

48. Servant G, Streva VA, Derbes RS, Wijetunge MI, Neeland M, White TB, et al. The nucleotide excision repair pathway limits L1 Retrotransposition. Genetics. 2017;205(1):139-53.

49. Evrony GD, Cai X, Lee E, Hills LB, Elhosary PC, Lehmann HS, et al. Singleneuron sequencing analysis of $L 1$ retrotransposition and somatic mutation in the human brain. Cell. 2012;151(3):483-96.

50. Evrony GD, Lee E, Mehta BK, Benjamini Y, Johnson RM, Cai X, et al. Cell lineage analysis in human brain using endogenous retroelements. Neuron. 2015:85(1):49-59.

51. Faulkner GJ, Billon V. L1 retrotransposition in the soma: a field jumping ahead. Mob DNA. 2018;9:22.

52. Gilbert N, Lutz S, Morrish TA, Moran JV. Multiple fates of L1 retrotransposition intermediates in cultured human cells. Mol Cell Biol. 2005;25(17):7780-95.

53. Moran JV, DeBerardinis RJ, Kazazian HH Jr. Exon shuffling by L1 retrotransposition. Science. 1999;283(5407):1530-4.
54. Szak ST, Pickeral OK, Landsman D, Boeke JD. Identifying related L1 retrotransposons by analyzing 3' transduced sequences. Genome Biol. 2003;4(5):R30.

55. Deininger P, Morales ME, White TB, Baddoo M, Hedges DJ, Servant G, et al. A comprehensive approach to expression of L1 loci. Nucleic Acids Res. 2017;45(5):e31.

56. Holmes SE, Dombroski BA, Krebs CM, Boehm CD, Kazazian HH Jr. A new retrotransposable human $\mathrm{L} 1$ element from the LRE2 locus on chromosome 1q produces a chimaeric insertion. Nat Genet. 1994;7(2):143-8.

57. Dewannieux M, Esnault C, Heidmann T. LINE-mediated retrotransposition of marked Alu sequences. Nat Genet. 2003;35(1):41-8.

58. Dewannieux M, Heidmann T. L1-mediated retrotransposition of murine B1 and B2 SINEs recapitulated in cultured cells. J Mol Biol. 2005;349(2):241-7.

59. Wallace N, Wagstaff BJ, Deininger PL, Roy-Engel AM. LINE-1 ORF1 protein enhances Alu SINE retrotransposition. Gene. 2008;419(1-2):1-6.

60. Wagstaff BJ, Hedges DJ, Derbes RS, Campos Sanchez R, Chiaromonte F, Makova $\mathrm{KD}$, et al. Rescuing Alu: recovery of new inserts shows LINE-1 preserves Alu activity through A-tail expansion. PLoS Genet. 2012;8(8):e1002842.

61. Kroutter EN, Belancio VP, Wagstaff BJ, Roy-Engel AM. The RNA polymerase dictates ORF1 requirement and timing of LINE and SINE retrotransposition. PLoS Genet. 2009;5(4):e1000458.

62. Wagstaff BJ, Barnerssoi M, Roy-Engel AM. Evolutionary conservation of the functional modularity of primate and murine LINE-1 elements. PLoS One. 2011;6(5):e19672.

63. Roy AM, Gong C, Kass DH, Deininger PL. Recent B2 element insertions in the mouse genome. DNA Seq. 1998;8(5):343-8.

64. Kass DH, Raynor ME, Williams TM. Evolutionary history of B1 retroposons in the genus Mus. J Mol Evol. 2000;51(3):256-64.

65. Bult CJ, Blake JA, Smith CL, Kadin JA, Richardson JE. Mouse Genome Database (MGD). Nucleic Acids Res. 2019:2018.

66. Zhang Y, Maksakova IA, Gagnier L, de Lagemaat LNV, Mager DL. Genomewide assessments reveal extremely high levels of polymorphism of two active families of mouse endogenous retroviral elements. PLoS Genet. 2008; 4(2):e1000007.

67. Li J, Akagi K, Hu Y, Trivett AL, Hlynialuk CJ, Swing DA, et al. Mouse endogenous retroviruses can trigger premature transcriptional termination at a distance. Genome Res. 2012;22(5):870-84.

68. Zhang Y, Romanish MT, Mager DL. Distributions of transposable elements reveal hazardous zones in mammalian introns. PLoS Comput Biol. 2011;7(5):e1002046.

69. Kuff EL, Lueders KK. The intracisternal A-particle gene family: structure and functional aspects. Adv Cancer Res. 1988;51:183-276.

70. Smit AFA, Hubley R, Grenn P. Repeatmasker Open 3.0. <http:// wwwrepeatmaskerorg >. 1996-2010.

71. Qin C, Wang Z, Shang J, Bekkari K, Liu R, Pacchione S, et al. Intracisternal a particle genes: distribution in the mouse genome, active subtypes, and potential roles as species-specific mediators of susceptibility to cancer. Mol Carcinog. 2010;49(1):54-67.

72. Lueders KK, Frankel WN, Mietz JA, Kuff EL. Genomic mapping of intracisternal A-particle proviral elements. Mamm Genome. 1993;4(2):69-77.

73. Reuss FU, Frankel WN, Moriwaki K, Shiroishi T, Coffin JM. Genetics of intracisternal-A-particle-related envelope-encoding proviral elements in mice. J Virol. 1996;70(9):6450-4.

74. Ribet D, Harper F, Dupressoir A, Dewannieux M, Pierron G, Heidmann T. An infectious progenitor for the murine IAP retrotransposon: emergence of an intracellular genetic parasite from an ancient retrovirus. Genome Res. 2008; 18(4):597-609.

75. Magiorkinis G, Gifford RJ, Katzourakis A, De Ranter J, Belshaw R. Env-less endogenous retroviruses are genomic superspreaders. Proc Natl Acad Sci. 2012;109(19):7385-90.

76. Dewannieux M, Dupressoir A, Harper F, Pierron G, Heidmann T. Identification of autonomous IAP LTR retrotransposons mobile in mammalian cells. Nat Genet. 2004;36(5):534-9.

77. E-s S, Keng WW, Takeda J, Horie K. Translation from nonautonomous type IAP retrotransposon is a critical determinant of transposition activity: implication for retrotransposon-mediated genome evolution. Genome Res. 2008;18(6):859-68.

78. Dupressoir A, Heidmann T. Germ line-specific expression of intracisternal Aparticle retrotransposons in transgenic mice. Mol Cell Biol. 1996;16(8):4495-503.

79. Peaston AE, Evsikov AV, Graber JH, de Vries WN, Holbrook AE, Solter D, et al. Retrotransposons regulate host genes in mouse oocytes and preimplantation embryos. Dev Cell. 2004;7(4):597-606. 
80. Mietz JA, Fewell JW, Kuff EL. Selective activation of a discrete family of endogenous proviral elements in normal BALB/c lymphocytes. Mol Cell Biol. 1992;12(1):220-8.

81. Kuff EL, Fewell JW. Intracisternal A-particle gene expression in normal mouse thymus tissue: gene products and strain-related variability. Mol Cell Biol. 1985:5(3):474-83.

82. Lueders KK, Fewell JW, Morozov VE, Kuff EL. Selective expression of intracisternal A-particle genes in established mouse plasmacytomas. Mol Cell Biol. 1993;13(12):7439-46.

83. Frankel WN, Mahaffey CL, McGarr TC, Beyer BJ, Letts VA. Unraveling genetic modifiers in the gria4 mouse model of absence epilepsy. PLoS Genet. 2014; 10(7):e1004454.

84. Walsh CP, Chaillet JR, Bestor TH. Transcription of IAP endogenous retroviruses is constrained by cytosine methylation. Nat Genet. 1998:20(2):116-7.

85. Maksakova I, Mager D, Reiss D. Keeping active endogenous retroviral-like sequences in check: the epigenetic persepective. Cellular and Molecular Life Sciences (CMLS). 2008;65(21):3329-47.

86. Leung DC, Lorincz MC. Silencing of endogenous retroviruses: when and why do histone marks predominate? Trends Biochem Sci. 2012;37(4):127-33.

87. Rowe HM, Trono D. Dynamic control of endogenous retroviruses during development. Virology. 2011;411(2):273-87.

88. Givol D. Activation of oncogenes by transposable elements. Biochem Soc Symp. 1986;51:183-96.

89. Wang XY, Steelman LS, McCubrey JA. Abnormal activation of cytokine gene expression by intracisternal type a particle transposition: effects of mutations that result in autocrine growth stimulation and malignant transformation. Cytokines Cell Mol Ther 1997;3(1):3-19.

90. Howard G, Eiges R, Gaudet F, Jaenisch R, Eden A. Activation and transposition of endogenous retroviral elements in hypomethylation induced tumors in mice. Oncogene. 2008;27(3):404-8.

91. Rakyan VK, Blewitt ME, Druker R, Preis JI, Whitelaw E. Metastable epialleles in mammals. Trends Genet. 2002;18(7):348-51.

92. Morgan HD, Sutherland HG, Martin DI, Whitelaw E. Epigenetic inheritance at the agouti locus in the mouse. Nat Genet. 1999;23(3):314-8.

93. Dolinoy DC, Das R, Weidman JR, Jirtle RL. Metastable Epialleles, imprinting, and the fetal origins of adult diseases. Pediatr Res. 2007;61:30R.

94. Kazachenka A, Bertozzi TM, Sjoberg-Herrera MK, Walker N, Gardner J, Gunning R, et al. Identification, Characterization, and Heritability of Murine Metastable Epialleles: Implications for Non-genetic Inheritance. Cell. 2018; 175(5):1259-71 e13.

95. Ishihara H, Tanaka I, Furuse M, Tsuneoka K. Increased expression of intracisternal A-particle RNA in regenerated myeloid cells after $X$ irradiation in C3H/He inbred mice. Radiat Res. 2000;153(4):392-7.

96. Ishihara H, Tanaka I, Wan H, Nojima K, Yoshida K. Retrotransposition of limited deletion type of intracisternal A-particle elements in the myeloid leukemia cells of C3H/He mice. J Radiat Res (Tokyo). 2004;45(1):25-32.

97. Barau J, Teissandier A, Zamudio N, Roy S, Nalesso V, Herault Y, et al. The DNA methyltransferase DNMT3C protects male germ cells from transposon activity. Science. 2016;354(6314):909-12.

98. Strong $\mathrm{LC}$. The establishment of the $\mathrm{C}(3) \mathrm{H}$ inbred strain of mice for the study of spontaneous carcinoma of the mammary gland. Genetics. 1935;20(6):586-91.

99. Heston WE, Vlahakis G. Mammary tumors, plaques, and hyperplastic alveolar nodules in various combinations of mouse inbred strains and the different lines of the mammary tumor virus. Int J Cancer. 1971;7(1):141-8.

100. Nandi S, McGrath CM. Mammary Neoplasia in Mice. In: Kleln G, Weinhouse S, Haddow A, editors. Advances in Cancer Research. 17. Cambridge: Academic Press; 1973. p. 353-414

101. Akeson EC, Donahue LR, Beamer WG, Shultz KL, Ackert-Bicknell C, Rosen CJ, et al. Chromosomal inversion discovered in $\mathrm{C} 3 \mathrm{H} / \mathrm{HeJ}$ mice. Genomics. 2006;87(2):311-3.

102. Schlager G, Dickie MM. Natural mutation rates in the house mouse. Estimates for five specific loci and dominant mutations. Mutat Res. 1971;11(1):89-96.

103. Brulet $P$, Kaghad M, Xu YS, Croissant O, Jacob F. Early differential tissue expression of transposon-like repetitive DNA sequences of the mouse. Proc Natl Acad Sci U S A. 1983;80(18):5641-5

104. Brûlet $P$, Condamine $H$, Jacob F. Spatial distribution of transcripts of the long repeated ETn sequence during early mouse embryogenesis. Proc Natl Acad Sci. 1985;82(7):2054-8.
105. Loebel DA, Tsoi B, Wong N, O'Rourke MP, Tam PP. Restricted expression of ETn-related sequences during post-implantation mouse development. Gene Expr Patterns. 2004;4(4):467-71.

106. Mager DL, Freeman JD. Novel mouse type $D$ endogenous proviruses and ETn elements share long terminal repeat and internal sequences. J Virol. 2000;74(16):7221-9.

107. Baust C, Gagnier L, Baillie GJ, Harris MJ, Juriloff DM, Mager DL. Structure and expression of mobile ETnll retroelements and their coding-competent MusD relatives in the mouse. J Virol. 2003;77(21):11448-58.

108. Ribet D, Dewannieux M, Heidmann T. An active murine transposon family pair: retrotransposition of "master" MusD copies and ETn trans-mobilization. Genome Res. 2004;14(11):2261-7.

109. Baust C, Baillie GJ, Mager DL. Insertional polymorphisms of ETn retrotransposons include a disruption of the wiz gene in C57BL/6 mice. Mamm Genome. 2002;13(8):423-8.

110. Ribet D, Harper F, Dewannieux M, Pierron G, Heidmann T. Murine MusD retrotransposon: structure and molecular evolution of an "intracellularized" retrovirus. J Virol. 2007;81(4):1888-98.

111. Maksakova IA, Zhang Y, Mager DL. Preferential epigenetic suppression of the autonomous MusD over the non-autonomous ETn mouse retrotransposons. Mol Cell Biol. 2009;29(9):2456-68.

112. Schorn AJ, Gutbrod MJ, LeBlanc C, Martienssen R. LTR-Retrotransposon Control by tRNA-Derived Small RNAs. Cell. 2017;170(1):61-71 e11.

113. Hofmann M, Harris M, Juriloff D, Boehm T. Spontaneous mutations in SELH/ Bc mice due to insertions of early transposons: molecular characterization of null alleles at thenudeandalbinoLoci. Genomics. 1998;52(1):107-9.

114. Juriloff DM, Macdonald KB, Harris MJ. Genetic analysis of the cause of exencephaly in the SELH/BC mouse stock. Teratology. 1989;40(4):395-405.

115. Smit AF. Interspersed repeats and other mementos of transposable elements in mammalian genomes. Curr Opin Genet Dev. 1999;9(6):657-63.

116. Medstrand $P$, van de Lagemaat LN, Mager DL. Retroelement distributions in the human genome: variations associated with age and proximity to genes. Genome Res. 2002;12(10):1483-95.

117. Perez B, Rodriguez-Pascau L, Vilageliu L, Grinberg D, Ugarte M, Desviat LR. Present and future of antisense therapy for splicing modulation in inherited metabolic disease. J Inherit Metab Dis. 2010;33(4):397-403.

118. Maksakova IA, Mager DL. Transcriptional regulation of early transposon elements, an active family of mouse long terminal repeat retrotransposons. J Virol. 2005;79(22):13865-74.

119. Hotta A, Cheung AY, Farra N, Vijayaragavan K, Seguin CA, Draper JS, et al. Isolation of human iPS cells using EOS lentiviral vectors to select for pluripotency. Nat Methods. 2009;6(5):370-6.

120. Lehoczky JA, Thomas PE, Patrie KM, Owens KM, Villarreal LM, Galbraith K, et al. A novel intergenic ETnll- $\beta$ insertion mutation causes multiple malformations in Polypodia mice. PLoS Genet. 2013;9(12):e1003967.

121. Sidow A, Bulotsky MS, Kerrebrock AW, Birren BW, Altshuler D, Jaenisch $\mathrm{R}$, et al. A novel member of the F-box/WD40 gene family, encoding dactylin, is disrupted in the mouse dactylaplasia mutant. Nat Genet. 1999:23(1):104-7.

122. Kano H, Kurahashi H, Toda T. Genetically regulated epigenetic transcriptional activation of retrotransposon insertion confers mouse dactylaplasia phenotype. Proc Natl Acad Sci. 2007;104(48):19034-9.

123. Friedli M, Nikolaev S, Lyle R, Arcangeli M, Duboule D, Spitz F, et al. Characterization of mouse Dactylaplasia mutations: a model for human ectrodactyly SHFM3. Mamm Genome. 2008;19(4):272-8.

124. Johnson KR, Lane PW, Ward-Bailey P, Davisson MT. Mapping the mouse dactylaplasia mutation, Dac, and a gene that controls its expression, mdac. Genomics. 1995;29(2):457-64

125. Krebs CJ, Larkins LK, Khan SM, Robins DM. Expansion and diversification of $K R A B$ zinc-finger genes within a cluster including regulator of sex-limitation 1 and 2. Genomics. 2005:85(6):752-61.

126. Wolf G, Greenberg D, Macfarlan TS. Spotting the enemy within: targeted silencing of foreign DNA in mammalian genomes by the Kruppel-associated box zinc finger protein family. Mob DNA. 2015:6:17.

127. Kozak CA. Origins of the endogenous and infectious laboratory mouse gammaretroviruses. Viruses. 2015;7(1):1-26.

128. Stoye JP, Coffin JM. Polymorphism of murine endogenous proviruses revealed by using virus class-specific oligonucleotide probes. J Virol. 1988;62(1):168-75.

129. Frankel WN, Stoye JP, Taylor BA, Coffin JM. A linkage map of endogenous murine leukemia proviruses. Genetics. 1990;124(2):221-36. 
130. Lock LF, Keshet E, Gilbert DJ, Jenkins NA, Copeland NG. Studies of the mechanism of spontaneous germline ecotropic provirus acquisition in mice. EMBO J. 1988;7(13):4169-77.

131. Jaenisch R. Germ line integration and Mendelian transmission of the exogenous Moloney leukemia virus. Proc Natl Acad Sci U S A. 1976:73(4):1260-4

132. Lock LF, Jenkins NA, Copeland NG. Mutagenesis of the mouse germline using retroviruses. Curr Top Microbiol Immunol. 1991;171:27-41.

133. Stanford WL, Cohn JB, Cordes SP. Gene-trap mutagenesis: past, present and beyond. Nat Rev Genet. 2001;2(10):756-68.

134. Kool J, Berns A. High-throughput insertional mutagenesis screens in mice to identify oncogenic networks. Nat Rev Cancer. 2009;9(6):389-99.

135. Jenkins NA, Copeland NG, Taylor BA, Lee BK. Dilute (d) coat colour mutation of DBA/2J mice is associated with the site of integration of an ecotropic MuLV genome. Nature. 1981;293(5831):370-4.

136. Seperack PK, Strobel MC, Corrow DJ, Jenkins NA, Copeland NG. Somatic and germ-line reverse mutation rates of the retrovirus-induced dilute coat-color mutation of DBA mice. Proc Natl Acad Sci U S A. 1988;85(1):189-92.

137. Stoye JP, Fenner S, Greenoak GE, Moran C, Coffin JM. Role of endogenous retroviruses as mutagens: the hairless mutation of mice. Cell. 1988;54(3):383-91.

138. Jurka J, Kapitonov W, Pavlicek A, Klonowski P, Kohany O, Walichiewicz J. Repbase update, a database of eukaryotic repetitive elements. Cytogenet Genome Res. 2005;110:462-7.

139. Flaherty JP, Fairfield HE, Spruce CA, McCarty CM, Bergstrom DE. Molecular characterization of an allelic series of mutations in the mouse Nox3 gene. Mamm Genome. 2011;22(3):156-69.

140. Semba K, Araki K, Matsumoto K-i, Suda H, Ando T, Sei A, et al. Ectopic Expression of Ptf1a Induces Spinal Defects, Urogenital Defects, and Anorectal Malformations in Danforth's Short Tail Mice. PLoS Genetics. 2013;9(2):e1003204.

141. Vlangos CN, Siuniak AN, Robinson D, Chinnaiyan AM, Lyons RH, Cavalcoli $J D$, et al. Next-generation sequencing identifies the Danforth's short tail mouse mutation as a retrotransposon insertion affecting Ptf1a expression. PLoS Genet. 2013;9(2):e1003205.

142. Lugani F, Arora R, Papeta N, Patel A, Zheng Z, Sterken R, et al. A retrotransposon insertion in the $5^{\prime}$ regulatory domain of Ptfla results in ectopic gene expression and multiple congenital defects in Danforth's short tail mouse. PLoS Genet. 2013;9(2):e1003206.

143. Bultman SJ, Michaud EJ, Woychik RP. Molecular characterization of the mouse agouti locus. Cell. 1992;71(7):1195-204.

144. French NS, Norton JD. Structure and functional properties of mouse VL30 retrotransposons. Biochim Biophys Acta (BBA) - Gene Struct Expr. 1997; 1352(1):33-47.

145. Markopoulos G, Noutsopoulos D, Mantziou S, Gerogiannis D, Thrasyvoulou $\mathrm{S}$, Vartholomatos $\mathrm{G}$, et al. Genomic analysis of mouse VL30 retrotransposons. Mob DNA. 2016;7:10

146. Benit L, Lallemand JB, Casella JF, Philippe H, Heidmann T. ERV-L elements: a family of endogenous retrovirus-like elements active throughout the evolution of mammals. J Virol. 1999;73(4):3301-8.

147. Costas J. Molecular characterization of the recent intragenomic spread of the murine endogenous retrovirus MuERV-L. J Mol Evol. 2003;56(2):181-6.

148. Blanco-Melo D, Gifford RJ, Bieniasz PD. Reconstruction of a replicationcompetent ancestral murine endogenous retrovirus-L. Retrovirology. 2018;15(1):34.

149. Kigami D, Minami N, Takayama H, Imai H. MuERV-L is one of the earliest transcribed genes in mouse one-cell embryos. Biol Reprod. 2003;68(2):651-4.

150. Ribet D, Louvet-Vallee S, Harper F, de Parseval N, Dewannieux M, Heidmann $\mathrm{O}$, et al. Murine endogenous retrovirus MuERV-L is the progenitor of the "orphan" epsilon viruslike particles of the early mouse embryo. J Virol. 2008;82(3):1622-5.

151. Daugherty MD, Malik HS. Rules of engagement: molecular insights from host-virus arms races. Annu Rev Genet. 2012;46:677-700.

152. Macfarlan TS, Gifford WD, Driscoll S, Lettieri K, Rowe HM, Bonanomi D, et al. Embryonic stem cell potency fluctuates with endogenous retrovirus activity. Nature. 2012;487(7405):57-63.

153. Franke V, Ganesh S, Karlic R, Malik R, Pasulka J, Horvat F, et al. Long terminal repeats power evolution of genes and gene expression programs in mammalian oocytes and zygotes. Genome Res. 2017;27(8): 1384-94.
154. Brind'Amour J, Kobayashi H, Richard Albert J, Shirane K, Sakashita A, Kamio A, et al. LTR retrotransposons transcribed in oocytes drive species-specific and heritable changes in DNA methylation. Nat Commun. 2018;9(1):3331.

155. Huang Y, Kim JK, Do DV, Lee C, Penfold CA, Zylicz JJ, et al. Stella modulates transcriptional and endogenous retrovirus programs during maternal-tozygotic transition. eLife. 2017;6.

156. Smit AF. Identification of a new, abundant superfamily of mammalian LTRtransposons. Nucleic Acids Res. 1993;21(8):1863-72.

157. Evsikov AV, de Vries WN, Peaston AE, Radford EE, Fancher KS, Chen FH, et al. Systems biology of the 2-cell mouse embryo. Cytogenet Genome Res. 2004; 105(2-4):240-50.

158. Mizuno S, lijima S, Okano T, Kajiwara N, Kunita S, Sugiyama F, et al. Retrotransposon-mediated Fgf5go-Utr mutant mice with long pelage hair. Exp Anim. 2011;60(2):161-7.

159. Loftus SK, Morris JA, Carstea ED, Gu JZ, Cummings C, Brown A, et al. Murine model of Niemann-pick C disease: mutation in a cholesterol homeostasis gene. Science. 1997;277(5323):232-5.

160. Kelly RG. Similar origins of two mouse Minisatellites within transposon-like LTRs. Genomics. 1994:24(3):509-15.

161. Mermer B, Colb M, Krontiris TG. A family of short, interspersed repeats is associated with tandemly repetitive DNA in the human genome. Proc Natl Acad Sci U S A. 1987;84(10):3320-4.

162. Chen J, Rattner A, Nathans J. Effects of L1 retrotransposon insertion on transcript processing, localization and accumulation: lessons from the retinal degeneration 7 mouse and implications for the genomic ecology of L1 elements. Hum Mol Genet. 2006;15(13):2146-56.

163. Besse S, Allamand V, Vilquin J-T, Li Z, Poirier C, Vignier N, et al. Spontaneous muscular dystrophy caused by a retrotransposal insertion in the mouse laminin a2 chain gene. Neuromuscul Disord. 2003;13(3):216-22.

164. Chang B, Grau T, Dangel S, Hurd R, Jurklies B, Sener EC, et al. A homologous genetic basis of the murine cpfl1 mutant and human achromatopsia linked to mutations in the PDE6C gene. Proc Natl Acad Sci. 2009;106(46):19581-6.

165. Geister KA, Brinkmeier ML, Cheung LY, Wendt J, Oatley MJ, Burgess DL, et al. LINE-1 mediated insertion into Pocla (protein of centriole 1 a) causes growth insufficiency and male infertility in mice. PLoS Genet. 2015;11(10):e1005569.

166. Chang DY, Newitt JA, Hsu K, Bernstein HD, Maraia RJ. A highly conserved nucleotide in the Alu domain of SRP RNA mediates translation arrest through high affinity binding to SRP9/14. Nucleic Acids Res. 1997;25(6):1117-22.

167. Bennett EA, Keller H, Mills RE, Schmidt S, Moran JV, Weichenrieder O, et al. Active Alu retrotransposons in the human genome. Genome Res. 2008; 18(12):1875-83

168. Lev-Maor G, Sorek R, Shomron N, Ast G. The Birth of an Alternatively Spliced Exon: 3\&\#039; Splice-Site Selection in \&lt;em\&gt;Alu\&lt;/em\&gt; Exons. Science. 2003;300(5623):1288.

169. Sela N, Mersch B, Gal-Mark N, Lev-Maor G, Hotz-Wagenblatt A, Ast G. Comparative analysis of transposed element insertion within human and mouse genomes reveals Alu's unique role in shaping the human transcriptome. Genome Biol. 2007;8(6):R127.

170. Kember RL, Fernandes C, Tunbridge EM, Liu L, Payá-Cano JL, Parsons MJ, et al. A B2 SINE insertion in the Comt1 gene (Comt1B2i) results in an overexpressing, behavior modifying allele present in classical inbred mouse strains. Genes Brain Behav. 2010;9(8):925-32.

171. Li Z, Mulligan MK, Wang X, Miles MF, Lu L, Williams RW. A transposon in Comt generates mRNA variants and causes widespread expression and behavioral differences among mice. PLoS One. 2010;5(8):e12181.

172. Lacey D, Hickey P, Arhatari BD, O'Reilly LA, Rohrbeck L, Kiriazis H, et al. Spontaneous retrotransposon insertion into TNF $3^{\prime} U$ TR causes heart valve disease and chronic polyarthritis. Proc Natl Acad Sci. 2015;112(31): 9698.

173. Druker R, Whitelaw E. Retrotransposon-derived elements in the mammalian genome: a potential source of disease. J Inherit Metab Dis. 2004:27(3):319-30

174. Saha PS, An W. Recently Mobilised Transposons in the Human Genome. 2019. In: eLS [Internet]. Chichester: John Wiley and Sons, Ltd. Available from: https://doi.org/10.1002/9780470015902.a0020837.

175. Stenson PD, Mort M, Ball EV, Evans K, Hayden M, Heywood S, et al. The human gene mutation database: towards a comprehensive repository of inherited mutation data for medical research, genetic diagnosis and nextgeneration sequencing studies. Hum Genet. 2017;136(6):665-77. 
176. Kazazian HH Jr. An estimated frequency of endogenous insertional mutations in humans. Nat Genet. 1999;22(2):130.

177. Wimmer K, Callens T, Wernstedt A, Messiaen L. The NF1 gene contains hotspots for L1 endonuclease-dependent de novo insertion. PLoS Genet. 2011;7(11):e1002371.

178. Goff SP. Retrovirus restriction factors. Mol Cell. 2004;16(6):849-59.

179. Molaro A, Malik HS. Hide and seek: how chromatin-based pathways silence retroelements in the mammalian germline. Curr Opin Genet Dev. 2016;37:51-8.

180. Goodier JL. Restricting retrotransposons: a review. Mob DNA. 2016;7:16.

181. Argeson AC, Nelson KK, Siracusa LD. Molecular basis of the pleiotropic phenotype of mice carrying the hypervariable yellow (Ahvy) mutation at the agouti locus. Genetics. 1996;142(2):557-67.

182. Michaud EJ, van Vugt MJ, Bultman SJ, Sweet HO, Davisson MT, Woychik RP. Differential expression of a new dominant agouti allele (Aiapy) is correlated with methylation state and is influenced by parental lineage. Genes Dev. 1994;8(12):1463-72.

183. Duhl DMJ, Vrieling H, Miller KA, Wolff GL, Barsh GS. Neomorphic agouti mutations in obese yellow mice. Nat Genet. 1994;8(1):59-65.

184. Banno F, Kaminaka K, Soejima K, Kokame K, Miyata T. Identification of strainspecific variants of mouse Adamts13 gene encoding von Willebrand factorcleaving protease. J Biol Chem. 2004;279(29):30896-903.

185. Zhou W, Bouhassira EE, Tsai H-M. An IAP retrotransposon in the mouse \&lt; em\&gt;ADAMTS13\&lt;/em\&gt; gene creates ADAMTS13 variant proteins that are less effective in cleaving von Willebrand factor multimers. Blood. 2007;110(3):886.

186. Kantheti P, Diaz ME, Peden A, Seong E, Dolan DF, Robinson MS, et al. Genetic and phenotypic analysis of the mouse mutant mh 2J, an Ap3d allele caused by IAP element insertion. Mamm Genome. 2003;14(3):157-67.

187. Bomar JM, Benke PJ, Slattery EL, Puttagunta R, Taylor LP, Seong E, et al. Mutations in a novel gene encoding a CRAL-TRIO domain cause human Cayman ataxia and ataxia/dystonia in the jittery mouse. Nat Genet. 2003:35(3):264-9.

188. X-y S, Z-y C, Hayashi Y, Kanou Y, Takagishi Y, S-i O, et al. Insertion of an intracisternal a particle retrotransposon element in plasma membrane calcium ATPase 2 gene attenuates its expression and produces an ataxic phenotype in joggle mutant mice. Gene. 2008;411(1-2):94-102.

189. Gunn TM, Inui T, Kitada K, Ito S, Wakamatsu K, He L, et al. Molecular and phenotypic analysis of Attractin mutant mice. Genetics. 2001;158(4):1683-95.

190. Vasicek TJ, Zeng L, Guan XJ, Zhang T, Costantini F, Tilghman SM. Two dominant mutations in the mouse fused gene are the result of transposon insertions. Genetics. 1997;147(2):777-86.

191. Rakyan VK, Chong S, Champ ME, Cuthbert PC, Morgan HD, Luu KVK, et al. Transgenerational inheritance of epigenetic states at the murine AxinFu allele occurs after maternal and paternal transmission. Proc Natl Acad Sci. 2003;100(5):2538-43.

192. Jia Y, Jucius TJ, Cook SA, Ackerman SL. Loss of Clcc1 results in ER stress, misfolded protein accumulation, and neurodegeneration. J Neurosci. 2015;35(7):3001-9.

193. Nag N, Peterson K, Wyatt K, Hess S, Ray S, Favor J, et al. Endogenous retroviral insertion in Cryge in the mouse No3 cataract mutant. Genomics. 2007:89(4):512-20.

194. Ware ML, Fox JW, González JL, Davis NM, Lambert de Rouvroit C, Russo CJ, et al. aberrant splicing of a mouse disabled homolog, mdab1, in the scrambler mouse. Neuron. 1997;19(2):239-49.

195. Sheldon M, Rice DS, D'Arcangelo G, Yoneshima H, Nakajima K, Mikoshiba K, et al. Scrambler and yotari disrupt the disabled gene and produce a reelerlike phenotype in mice. Nature. 1997;389(6652):730-3.

196. Conner ME, King TR. The spontaneous juvenile alapecia (jal) mutation in mice is associated with the insertion of an IAP element in the Gata3 gene. Cogent Biol. 2016:2:1264691. https://www.tandfonline.com/doi/abs/10.1080/ 23312025.2016.1264691

197. Peachey Neal S, Ray Thomas A, Florijn R, Rowe Lucy B, Sjoerdsma T, Contreras-Alcantara S, et al. GPR179 is required for depolarizing bipolar cell function and is mutated in autosomal-recessive complete congenital stationary night blindness. Am J Hum Genet. 2012;90(2):331-9.

198. Chang B. Survey of the nob5 mutation in C3H substrains. Mol Vis. 2015;21:1101-5.

199. Beyer B, Deleuze C, Letts VA, Mahaffey CL, Boumil RM, Lew TA, et al. Absence seizures in $\mathrm{C} 3 \mathrm{H} / \mathrm{HeJ}$ and knockout mice caused by mutation of the AMPA receptor subunit Gria4. Hum Mol Genet. 2008;17(12): $1738-49$.
200. Gwynn B, Lueders K, Sands MS, Birkenmeier EH. Intracisternal A-particle element transposition into the murine $\beta$-Glucuronidase gene correlates with loss of enzyme activity: a new model for $\beta$-Glucuronidase deficiency in the C3H mouse. Mol Cell Biol. 1998;18(11):6474-81.

201. Suzuki T, Li W, Zhang Q, Novak EK, Sviderskaya EV, Wilson A, et al. The gene mutated in cocoa mice, carrying a defect of organelle biogenesis, is a homologue of the human Hermansky-Pudlak Syndrome-3 gene. Genomics. 2001;78(1-2):30-7.

202. Gardner JM, Wildenberg SC, Keiper NM, Novak EK, Rusiniak ME, Swank RT, et al. The mouse pale ear (ep) mutation is the homologue of human Hermansky-Pudlak syndrome. Proc Natl Acad Sci. 1997;94(17):9238-43.

203. Zhang Q, Zhao B, Li W, Oiso N, Novak EK, Rusiniak ME, et al. Ru2 and Ru encode mouse orthologs of the genes mutated in human HermanskyPudlak syndrome types 5 and 6. Nat Genet. 2003;33(2):145-53.

204. Elso CM, Lu X, Culiat CT, Rutledge JC, Cacheiro NLA, Generoso WM, et al. Heightened susceptibility to chronic gastritis, hyperplasia and metaplasia in Kcnq1 mutant mice. Hum Mol Genet. 2004;13(22):2813-21.

205. Kuster JE, Guarnieri MH, Ault JG, Flaherty L, Swiatek PJ. IAP insertion in the murine LamB3 gene results in junctional epidermolysis bullosa. Mamm Genome. 1997;8(9):673-81.

206. Potter PK, Bowl MR, Jeyarajan P, Wisby L, Blease A, Goldsworthy ME, et al. Novel gene function revealed by mouse mutagenesis screens for models of age-related disease. Nat Commun. 2016;7:12444.

207. Phan LK, Lin F, LeDuc CA, Chung WK, Leibel RL. The mouse mahoganoid coat color mutation disrupts a novel C3HC4 RING domain protein. J Clin Investig. 2002;110(10):1449-59.

208. He L, Lu X-Y, Jolly AF, Eldridge AG, Watson SJ, Jackson PK, et al. Spongiform degeneration in mahoganoid mutant mice. Science. 2003;299(5607):710.

209. Han W, Kasai S, Hata H, Takahashi T, Takamatsu Y, Yamamoto H, et al. Intracisternal A-particle element in the $3^{\prime}$ noncoding region of the muopioid receptor gene in CXBK mice: a new genetic mechanism underlying differences in opioid sensitivity. Pharmacogenet Genomics. 2006;16(6):451-60.

210. Hamilton BA, Smith DJ, Mueller KL, Kerrebrock AW, Bronson RT, van Berkel $V$, et al. The vibrator mutation causes neurodegeneration via reduced expression of PITPa: positional complementation cloning and Extragenic suppression. Neuron. 1997;18(5):711-22.

211. Strokin M, Seburn KL, Cox GA, Martens KA, Reiser G. Severe disturbance in the $\mathrm{ca}(2+)$ signaling in astrocytes from mouse models of human infantile neuroaxonal dystrophy with mutated Pla2g6. Hum Mol Genet. 2012;21(12):2807-14

212. Runkel F, Hintze M, Griesing S, Michels M, Blanck B, Fukami K, et al. Alopecia in a viable phospholipase $C$ delta 1 and phospholipase $C$ delta 3 double mutant. PLoS One. 2012;7(6):e39203.

213. Schuster-Gossler K, Harris B, Johnson KR, Serth J, Gossler A. Notch signalling in the paraxial mesoderm is most sensitive to reduced Pofut1 levels during early mouse development. BMC Dev Biol. 2009;9(1):6.

214. Royaux I, Bernier B, Montgomery JC, Flaherty L, Goffinet AM. Relnrl-Alb2,an Allele ofReelerlsolated from a Chlorambucil Screen, Is Due to an IAP Insertion with Exon Skipping. Genomics. 1997;42(3):479-82.

215. Chintala S, Tan J, Gautam R, Rusiniak ME, Guo X, Li W, et al. The Slc35d3 gene, encoding an orphan nucleotide sugar transporter, regulates plateletdense granules. Blood. 2007;109(4):1533-40.

216. Wandersee NJ, Roesch AN, Hamblen NR, de Moes J, van der Valk MA, Bronson RT, et al. Defective spectrin integrity and neonatal thrombosis in the first mouse model for severe hereditary elliptocytosis. Blood. 2001;97(2):543.

217. Hosur V, Cox ML, Burzenski LM, Riding RL, Alley L, Lyons BL, et al. Retrotransposon insertion in the T-cell acute lymphocytic leukemia 1 (Tal1) gene is associated with severe renal disease and patchy alopecia in Hairpatches (Hpt) mice. PLoS One. 2013;8(1):e53426.

218. Amanna IJ, Dingwall JP, Hayes CE. Enforced bcl-xL gene expression restored splenic B lymphocyte development in BAFF-R mutant mice. J Immunol. 2003;170(9):4593-600.

219. Wu M, Rinchik EM, Wilkinson E, Johnson DK. Inherited somatic mosaicism caused by an intracisternal a particle insertion in the mouse tyrosinase gene. Proc Natl Acad Sci. 1997;94(3):890-4.

220. Wilson SM, Bhattacharyya B, Rachel RA, Coppola V, Tessarollo L, Householder DB, et al. Synaptic defects in ataxia mice result from a mutation in Usp14, encoding a ubiquitin-specific protease. Nat Genet. 2002;32(3):420-5. 
221. Juriloff DM, Harris MJ, Dewell SL, Brown CJ, Mager DL, Gagnier L, et al. Investigations of the genomic region that contains theclf1 mutation, a causal gene in multifactorial cleft lip and palate in mice. Birth Defects Res A Clin Mol Teratol. 2005;73(2):103-13.

222. Juriloff DM, Harris MJ, Mager DL, Gagnier L. Epigenetic mechanism causes Wnt9b deficiency and nonsyndromic cleft lip and palate in the a/WySn mouse strain. Birth Defects Res A Clin Mol Teratol. 2014;100(10): 772-88.

223. Scherneck S, Nestler M, Vogel H, Blüher M, Block M-D, Diaz MB, et al. Positional cloning of zinc finger domain transcription factor Zfp69, a candidate gene for obesity-associated diabetes contributed by mouse locus Nidd/SJL. PLoS Genet. 2009;5(7):e1000541.

224. Jiao $Y$, Jin X, Yan J, Jiao F, Li X, Roe BA, et al. An insertion of intracisternal Aparticle retrotransposon in a novel member of the phosphoglycerate mutase family in the lew allele of mutant mice. Genes Genet Syst. 2009;84(5):327-34.

225. Wang L, Jiao Y, Sun S, Jarrett HW, Sun D, Gu W. Gene network of a phosphoglycerate mutase in muscle wasting in mice. Cell Biol Int. 2015;39(6):666-77.

226. Abdel-Majid RM, Leong WL, Schalkwyk LC, Smallman DS, Wong ST, Storm DR, et al. Loss of adenylyl cyclase I activity disrupts patterning of mouse somatosensory cortex. Nat Genet. 1998;19(3):289-91.

227. Leong WL, Dobson MJ, Logsdon JJM, Abdel-Majid RM, Schalkwyk LC, Guernsey DL, et al. ETn insertion in the mouse Adcyl gene: transcriptional and phylogenetic analyses. Mamm Genome. 2000;11(2):97-103.

228. Zhang Q, Li W, Novak EK, Karim A, Mishra VS, Kingsmore SF, et al. The gene for the muted (mu) mouse, a model for Hermansky-Pudlak syndrome, defines a novel protein which regulates vesicle trafficking. Hum Mol Genet. 2002;11(6):697-706.

229. Chang BO, Heckenlively JR, Bayley PR, Brecha NC, Davisson MT, Hawes NL, et al. The nob2 mouse, a null mutation in Cacna1f: anatomical and functional abnormalities in the outer retina and their consequences on ganglion cell visual responses. Vis Neurosci. 2006;23(1):11-24.

230. Doering CJ, Rehak R, Bonfield S, Peloquin JB, Stell WK, Mema SC, et al. Modified Cav1.4 Expression in the Cacna1fnob2 Mouse Due to Alternative Splicing of an ETn Inserted in Exon 2. PLOS ONE. 2008;3(7):e2538.

231. Letts VA, Felix R, Biddlecome GH, Arikkath J, Mahaffey CL, Valenzuela A, et al. The mouse stargazer gene encodes a neuronal Ca2+-channel gamma subunit. Nat Genet. 1998;19(4):340-7.

232. Letts VA, Kang M-G, Mahaffey CL, Beyer B, Tenbrink H, Campbell KP, et al. Phenotypic heterogeneity in the stargazin allelic series. Mamm Genome. 2003;14(8):506-13.

233. Schnülle V, Antropova O, Gronemeier M, Wedemeyer N, Jockusch H, Bartsch JW. The mouse Clc1 /myotonia gene: ETn insertion, a variable AATC repeat, and PCR diagnosis of alleles. Mamm Genome. 1997;8(10):718-25.

234. Zhang M-C, Furukawa H, Tokunaka K, Saiga K, Date F, Owada Y, et al. Mast cell hyperplasia in the skin of Dsg4-deficient hypotrichosis mice, which are long-living mutants of lupus-prone mice. Immunogenetics. 2008;60(10):599-607.

235. Ho M, Post CM, Donahue LR, Lidov HGW, Bronson RT, Goolsby H, et al. Disruption of muscle membrane and phenotype divergence in two novel mouse models of dysferlin deficiency. Hum Mol Genet. 2004;13(18):1999-2010.

236. Headon DJ, Overbeek PA. Involvement of a novel Tnf receptor homologue in hair follicle induction. Nat Genet. 1999;22(4):370-4.

237. Croquelois A, Giuliani F, Savary C, Kielar M, Amiot C, Schenk F, et al. Characterization of the HeCo mutant mouse: a new model of subcortical band heterotopia associated with seizures and behavioral deficits. Cereb Cortex. 2009;19(3):563-75.

238. Kielar M, Tuy FPD, Bizzotto S, Lebrand C, de Juan RC, Poirier K, et al. Mutations in Eml1 lead to ectopic progenitors and neuronal heterotopia in mouse and human. Nat Neurosci. 2014;17:923-33.

239. Chu JL, Drappa J, Parnassa A, Elkon KB. The defect in Fas mRNA expression in MRL/lpr mice is associated with insertion of the retrotransposon, ETn. J Exp Med. 1993;178(2):723.

240. Wu J, Zhou T, He J, Mountz JD. Autoimmune disease in mice due to integration of an endogenous retrovirus in an apoptosis gene. J Exp Med. 1993;178(2):461-8.

241. Chow CY, Zhang Y, Dowling JJ, Jin N, Adamska M, Shiga K, et al. Mutation of FIG4 causes neurodegeneration in the pale tremor mouse and patients with CMT4J. Nature. 2007:448(7149):68-72.
242. Cox GA, Mahaffey CL, Nystuen A, Letts VA, Frankel WN. The mouse fidgetin gene defines a new role for AAA family proteins in mammalian development. Nat Genet. 2000;26(2):198-202.

243. Thien H, Rüther $U$. The mouse mutation Pdn (polydactyly Nagoya) is caused by the integration of a retrotransposon into the Gli 3 gene. Mamm Genome. 1999;10(3):205-9.

244. Peters LL, Lane PW, Andersen SG, Gwynn B, Barker JE, Beutler E. Downeast Anemia (dea), a new mouse model of severe Nonspherocytic hemolytic Anemia caused by hexokinase (HKI) deficiency. Blood Cell Mol Dis. 2001; 27(5):850-60.

245. Talamas E, Jackson L, Koeberl M, Jackson T, McElwee JL, Hawes NL, et al. Early transposable element insertion in intron 9 of the $\mathrm{Hsf4}$ gene results in autosomal recessive cataracts in lop11 and Idis1 mice. Genomics. 2006;88(1):44-51.

246. Shiels A, Bassnett S. Mutations in the founder of the MIP gene family underlie cataract development in the mouse. Nat Genet. 1996;12(2):212-5.

247. Shiels A, Mackay D, Bassnett S, Al-ghoul K, Kuszak J. Disruption of lens fiber cell architecture in mice expressing a chimeric AQPO-LTR protein. FASEB J. 2000;14(14):2207-12.

248. Roberts KA, Abraira VE, Tucker AF, Goodrich LV, Andrews NC. Mutation of Rubie, a novel long non-coding RNA located upstream of Bmp4, causes vestibular malformation in mice. PLoS One. 2012;7(1):e29495.

249. Mecklenburg L, Tobin DJ, Cirlan MV, Craciun C, Paus R. Premature termination of hair follicle morphogenesis and accelerated hair follicle cycling in lasi congenital atrichia (fzica) mice points to fuzzy as a key element of hair cycle control. Exp Dermatol. 2005;14(8):561-70.

250. Campagna DR, Custodio ÁO, Antiochos BB, Cirlan MV, Fleming MD. Mutations in the serum/glucocorticoid regulated kinase 3 (Sgk3) are responsible for the mouse fuzzy (fz) hair phenotype. J Investig Dermatol. 2008;128(3):730-2.

251. Zhao L, Longo-Guess C, Harris BS, Lee J-W, Ackerman SL. Protein accumulation and neurodegeneration in the woozy mutant mouse is caused by disruption of SIL 1, a cochaperone of BiP. Nat Genet. 2005;37:974-9.

252. Bogdanik LP, Chapman HD, Miers KE, Serreze DV, Burgess RW. A MusD retrotransposon insertion in the mouse Slc6a5 gene causes alterations in neuromuscular junction maturation and behavioral phenotypes. PLoS One. 2012;7(1):e30217.

253. White RA, McNulty SG, Nsumu NN, Boydston LA, Brewer BP, Shimizu K. Positional cloning of the Ttc7 gene required for normal iron homeostasis and mutated in hea and fsn anemia mice. Genomics. 2005:85(3):330-7.

254. Herrmann BG, Labeit S, Poustka A, King TR, Lehrach $H$. Cloning of the $T$ gene required in mesoderm formation in the mouse. Nature. 1990; 343(6259):617-22

255. Goldin SN, Papaioannou VE. Unusual misregulation of RNA splicing caused by insertion of a transposable element into the T (Brachyury) locus. BMC Genomics. 2003;4(1):14.

256. Perincheri S, Dingle RWC, Peterson ML, Spear BT. Hereditary persistence of -fetoprotein and $\mathrm{H} 19$ expression in liver of BALB/CJ mice is due to a retrovirus insertion in the $\mathrm{Zh} \times 2$ gene. Proc Natl Acad Sci. 2004;102(2):396-401.

257. Perincheri S, Peyton DK, Glenn M, Peterson ML, Spear BT. Characterization of the ETnll-a endogenous retroviral element in the BALB/CJ Zhx2 Afr1 allele. Mamm Genome. 2007;19(1):26-31.

258. Jun K, Lee S-B, Shin H-S. Insertion of a retroviral solo long terminal repeat in mdr-3 locus disrupts mRNA splicing in mice. Incorporating Mouse Genome. 2000;11(10):843-8.

259. Pippert TR, Umbenhauer DR. The subpopulation of CF-1 mice deficient in Pglycoprotein contains a murine retroviral insertion in themdr1a gene. J Biochem Mol Toxicol. 2001;15(2):83-9.

260. Klein JA, Longo-Guess CM, Rossmann MP, Seburn KL, Hurd RE, Frankel WN, et al. The harlequin mouse mutation downregulates apoptosis-inducing factor. Nature. 2002;419(6905):367-74

261. Bubier JA, Sproule TJ, Alley LM, Webb CM, Fine JD, Roopenian DC, et al. A mouse model of generalized non-Herlitz junctional epidermolysis bullosa. J Invest Dermatol. 2010;130(7):1819-28.

262. Péterfy M, Ben-Zeev O, Mao HZ, Weissglas-Volkov D, Aouizerat BE, Pullinger $C R$, et al. Mutations in LMF1 cause combined lipase deficiency and severe hypertriglyceridemia. Nat Genet. 2007;39(12):1483-7. 
263. Bowes C, Li T, Frankel WN, Danciger M, Coffin JM, Applebury ML, et al. Localization of a retroviral element within the rd gene coding for the beta subunit of cGMP phosphodiesterase. Proc Natl Acad Sci U S A. 1993;90(7):2955-9.

264. Fernandez-Gonzalez A, Spada ARL, Treadaway J, Higdon JC, Harris BS, Sidman RL, et al. Purkinje cell degeneration (pcd) phenotypes caused by mutations in the Axotomy-induced gene, Nnal. Science. 2002;295(5561):1904-6.

265. Paffenholz R, Bergstrom RA, Pasutto F, Wabnitz P, Munroe RJ, Jagla W, et al. Vestibular defects in head-tilt mice result from mutations in Nox3, encoding an NADPH oxidase. Genes Dev. 2004;18(5):486-91.

266. Travis GH, Brennan MB, Danielson PE, Kozak CA, Sutcliffe JG. Identification of a photoreceptor-specific mRNA encoded by the gene responsible for retinal degeneration slow (rds). Nature. 1989;338(6210):70-3.

267. Ma J, Norton JC, Allen AC, Burns JB, Hasel KW, Burns JL, et al. Retinal degeneration slow (rds) in mouse results from simple insertion of a $t$ haplotype-specific element into protein-coding exon II. Genomics. 1995;28(2):212-9.

268. Yamada T, Ohtani S, Sakurai T, Tsuji T, Kunieda T, Yanagisawa M. Reduced expression of the endothelin receptor type $B$ gene in piebald mice caused by insertion of a retroposon-like element in intron 1. J Biol Chem. 2006; 281(16):10799-807.

269. Wooley GW. "misty" a new coat color dilution in the mouse, Mus musculus. Am Nat. 1941;75(760):507-8.

270. Blasius AL, Brandl K, Crozat K, Xia Y, Khovananth K, Krebs P, et al. Mice with mutations of Dock7 have generalized hypopigmentation and whitespotting but show normal neurological function. Proc Natl Acad Sci. 2009; 106(8):2706-11.

271. Conti V, Aghaie A, Cilli M, Martin N, Caridi G, Musante L, et al. crv4, a mouse model for human ataxia associated with kyphoscoliosis caused by an mRNA splicing mutation of the metabotropic glutamate receptor 1 (Grm1). Int J Mol Med. 2006;18(4):593-600.

272. Cunliffe $P$, Reed $V$, Boyd Y. Intragenic deletions at Atp7a in mouse models for Menkes disease. Genomics. 2001;74(2):155-62.

273. Kojima T, Nakajima K, Mikoshiba K. The disabled 1 gene is disrupted by a replacement with $\mathrm{L} 1$ fragment in yotari mice. Mol Brain Res. 2000;75(1):121-7.

274. Smyth I, Du X, Taylor MS, Justice MJ, Beutler B, Jackson IJ. The extracellular matrix gene Frem1 is essential for the normal adhesion of the embryonic epidermis. Proc Natl Acad Sci U S A. 2004;101(37):13560-5.

275. Kingsmore SF, Giros B, Suh D, Bieniarz M, Caron MG, Seldin MF. Glycine receptor $\beta$-subunit gene mutation in spastic mouse associated with LINE-1 element insertion. Nat Genet. 1994;7(2):136-42.

276. Mulhardt C, Fischer M, Gass P, Simon-Chazottes D, Guenet JL, Kuhse J, et al. The spastic mouse: aberrant splicing of glycine receptor beta subunit mRNA caused by intronic insertion of L1 element. Neuron. 1994;13(4):1003-15.

277. Becker K, Braune M, Benderska N, Buratti E, Baralle F, Villmann C, et al. A Retroelement modifies pre-mRNA splicing: THE Murine Glrbspa allele is a splicing signal polymorphism amplified by a long interspersed nuclear element insertion. J Biol Chem. 2012;287(37):31185-94.

278. Perou CM, Moore KJ, Nagle DL, Misumi DJ, Woolf EA, McGrail SH, et al. Identification of the murine beige gene by YAC complementation and positional cloning. Nat Genet. 1996;13(3):303-8.

279. Perou CM, Pryor RJ, Naas TP, Kaplan J. ThebgAllele mutation is due to a LINE1 element Retrotransposition. Genomics. 1997;42(2):366-8.

280. Yajima I, Sato S, Kimura T, Ki Y, Shibahara S, Goding CR, et al. an L1 element Intronic insertion in the black-eyed White (Mitfmi-bw) gene: the loss of a single Mitf isoform responsible for the pigmentary defect and inner ear deafness. Hum Mol Genet. 1999;8(8):1431-41.

281. Takahara T, Ohsumi T, Kuromitsu J, Shibata K, Sasaki N, Okazaki Y, et al. Dysfunction of the Orleans Reeler gene arising from exon skipping due to transposition of a full-length copy of an active $L 1$ sequence into the skipped exon. Hum Mol Genet. 1996;5(7):989-93.

282. Kohrman DC, Harris JB, Meisler MH. Mutation detection in the med and medJ alleles of the Sodium Channel Scn8a: Unusual splicing due to a minor class AT-AC Intron. J Biol Chem. 1996;271(29):17576-81.

283. Garvey SM, Rajan C, Lerner AP, Frankel WN, Cox GA. The muscular dystrophy with myositis (mdm) mouse mutation disrupts a skeletal musclespecific domain of titin. Genomics. 2002;79(2):146-9.
284. Gilbert N, Bomar JM, Burmeister M, Moran JV. Characterization of a mutagenic $B 1$ retrotransposon insertion in the jittery mouse. Hum Mutat. 2004;24(1):9-13.

285. Lunny DP, Weed E, Nolan PM, Marquardt A, Augustin M, Porter RM. Mutations in gasdermin 3 cause aberrant differentiation of the hair follicle and sebaceous gland. J Invest Dermatol. 2005;124(3):615-21.

286. Leong DW, Komen JC, Hewitt CA, Arnaud E, McKenzie M, Phipson B, et al. Proteomic and Metabolomic analyses of mitochondrial complex I-deficient mouse model generated by spontaneous B2 short interspersed nuclear element (SINE) insertion into NADH dehydrogenase (ubiquinone) Fe-S protein 4 (Ndufs4) gene. J Biol Chem. 2012;287(24):20652-63.

287. Morelli KH, Seburn KL, Schroeder DG, Spaulding EL, Dionne LA, Cox GA, et al. Severity of demyelinating and axonal neuropathy mouse models is modified by genes affecting structure and function of peripheral nodes. Cell Rep. 2017;18(13):3178-91.

288. Nesterovitch AB, Szanto S, Gonda A, Bardos T, Kis-Toth K, Adarichev VA, et al. Spontaneous insertion of a b2 element in the ptpn 6 gene drives a systemic autoinflammatory disease in mice resembling neutrophilic dermatosis in humans. Am J Pathol. 2011;178(4):1701-14.

289. Moulson CL, Martin DR, Lugus JJ, Schaffer JE, Lind AC, Miner JH. Cloning of wrinkle-free, a previously uncharacterized mouse mutation, reveals crucial roles for fatty acid transport protein 4 in skin and hair development. Proc Natl Acad Sci U S A. 2003;100(9):5274-9.

\section{Ready to submit your research? Choose BMC and benefit from:}

- fast, convenient online submission

- thorough peer review by experienced researchers in your field

- rapid publication on acceptance

- support for research data, including large and complex data types

- gold Open Access which fosters wider collaboration and increased citations

- maximum visibility for your research: over $100 \mathrm{M}$ website views per year

At BMC, research is always in progress.

Learn more biomedcentral.com/submissions 